\title{
Effect on the Antioxidant, Lipoperoxyl Radical Scavenger Capacity, Nutritional, Sensory and Microbiological Traits of an Ovine Stretched Cheese Produced with Grape Pomace Powder Addition
}

\author{
Raimondo Gaglio ${ }^{1}$, Ignazio Restivo ${ }^{2}$ D, Marcella Barbera ${ }^{1}$, Pietro Barbaccia ${ }^{1}$, Marialetizia Ponte ${ }^{1}$, \\ Luisa Tesoriere $^{2} \mathbb{D}$, Adriana Bonanno ${ }^{1} \mathbb{D}$, Alessandro Attanzio ${ }^{2} \mathbb{D}$, Antonino Di Grigoli ${ }^{1} \mathbb{D}$, Nicola Francesca $^{1} \mathbb{D}$, \\ Giancarlo Moschetti ${ }^{1}$ (D) and Luca Settanni ${ }^{1, *}$ (D)
}

check for updates

Citation: Gaglio, R.; Restivo, I.; Barbera, M.; Barbaccia, P.; Ponte, M.; Tesoriere, L.; Bonanno, A.; Attanzio, A.; Di Grigoli, A.; Francesca, N.; et al. Effect on the Antioxidant,

Lipoperoxyl Radical Scavenger Capacity, Nutritional, Sensory and Microbiological Traits of an Ovine Stretched Cheese Produced with Grape Pomace Powder Addition. Antioxidants 2021, 10, 306. https:// doi.org/10.3390/antiox10020306

Academic Editor: Marc Pignitter

Received: 11 January 2021

Accepted: 9 February 2021

Published: 17 February 2021

Publisher's Note: MDPI stays neutral with regard to jurisdictional claims in published maps and institutional affiliations.

Copyright: (c) 2021 by the authors. Licensee MDPI, Basel, Switzerland. This article is an open access article distributed under the terms and conditions of the Creative Commons Attribution (CC BY) license (https:/ / creativecommons.org/licenses/by/ $4.0 /)$.
1 Dipartimento Scienze Agrarie, Alimentari e Forestali, Ed. 5, Università degli Studi di Palermo, Viale delle Scienze, 90128 Palermo, Italy; raimondo.gaglio@unipa.it (R.G.); marcella.barbera@unipa.it (M.B.); pietro.barbaccia@unipa.it (P.B.); marialetizia.ponte@unipa.it (M.P.); adriana.bonanno@unipa.it (A.B.); antonino.digrigoli@unipa.it (A.D.G.); nicola.francesca@unipa.it (N.F.); giancarlo.moschetti@unipa.it (G.M.)

2 Dipartimento di Scienze e Tecnologie Biologiche, Chimiche e Farmaceutiche, Università degli Studi di Palermo, Via Archirafi 34, 90123 Palermo, Italy; ignazio.restivo@unipa.it (I.R.); luisa.tesoriere@unipa.it (L.T.); alessandro.attanzio@unipa.it (A.A.)

* Correspondence: luca.settanni@unipa.it; Tel.: +39-091-23896043; Fax: +39-091-6515531

\begin{abstract}
An innovative ovine cheese enriched with red grape pomace powder (GPP) was produced to improve the functional properties of Vastedda cheese typology. Vastedda cheese making was performed adding GPP and four selected Lactococcus lactis strains (Mise36, Mise94, Mise169 and Mise190). For each strain, $40 \mathrm{~L}$ of pasteurized ewe's milk was divided into two aliquots representing control and experimental trials. Control cheese (CC) production did not contain GPP, while the experimental cheese (EC) production was enriched with 1\% (w/w) GPP. GPP did not slow down starter development and acid generation. Plate counts and randomly amplified polymorphic DNA (RAPD)-PCR analysis confirmed the dominance of the starters in all trials. The evolution of the physicochemical parameters showed that EC productions were characterized by lower fat content, higher protein content, and higher values of secondary lipid oxidation. Sensory evaluation indicated that the cheeses produced with the strain Mise94 were those more appreciated by the judges. Thus, the last cheeses were investigated for some functional aspects: GPP enrichment significantly increased antioxidant activity and lipoperoxyl radical scavenger capacity, confirming that grape polyphenol inclusion in cheese represents an optimal strategy for the valorization of ovine cheeses as well as winemaking industry by-products.
\end{abstract}

Keywords: antioxidants; grape pomace powder; Lactococcus lactis; lipoperoxyl radical scavenger capacity; ovine stretched cheese; polyphenols; volatile organic compounds

\section{Introduction}

Nowadays, natural antioxidants extracted from plant by-products represent a useful source of active compounds to produce healthy and functional foods more and more requested by consumers [1]. In order to face this increasing demand, in the last years, the food industries also focused the attention toward dairy products. Thus, several efforts are being made to enrich dairy products such as cheeses with functional and antioxidant components [2] because these foods are basically poor in bioactive compounds [3].

The most interesting natural antioxidants belong to the chemical classes of phenols [4]. They are particularly present in some fruits such as red grape [5]. Thus, winemaking industry by-products constitute an interesting source of bioactive phenolic compounds [6]. The main by-products generated during the winemaking process are composed by a mix 
of grape seeds and skins [7], namely grape pomace, which represents approximately $20-25 \%$ of the grapes at harvest [8]. The wine industry produces millions of tons of grape pomace with several environmental and economic implications [9]. These by-products are characterized by high contents of antioxidant polyphenols and dietary fiber with potential beneficial effects on human health, including antioxidant activity and antimicrobial, antiinflammatory, anticancer, and cardiovascular properties [10].

Grape pomace in powder (GPP) has been added to several food formulations including cereal-based foods [11], meat [12], and fish [13] products as well as cheeses [7,14] in order to increase their antioxidant activity and dietary fiber content. Regarding GPP addition to cheese, so far, this application has only been performed for bovine milk derived cheeses.

In Italy, dairy sheep farming is particularly located in the islands of Sardinia and Sicily and in central regions. Sheep milk produced in Sicily derives mainly from ewes of Valle del Belice and Comisana local breeds fed pasture-based diets and is processed to manufacture dairy products at industrial or farm level. Sicily region valorized some of its dairy productions by means of the recognition of quality status like Protected Designation of Origin (PDO), but due to their scarce reputation in terms of healthy properties, cheeses, especially those processed from ewe's milk, are considered as unsuitable for a valuable nutrition by the majority of people. For this reason, in the last years, several breeders and cheese producers pushed research institutes to develop dairy functional foods in order to contribute to the rural development. This issue is particularly relevant for the Mediterranean area because the production of cheeses is important for the environmental sustainability, makes advantageous the maintenance of native breeds, allows the survival of handicraft techniques, limits the land abandonment phenomenon, and a renewed interest for high-quality, safe products can increase the employment for livestock raising and milk transformation and have an appreciable impact on the local economy.

With this in mind, in this work a novel fresh-stretched ewes' milk cheese was produced with the addition of GPP using four lactic acid bacteria (LAB) strains individually. These LAB were previously selected for their resistance in presence of the main grape polyphenols [15]. The final cheeses were subjected to the evaluation of the microbiological, physicochemical, sensory, and functional aspects.

\section{Materials and Methods}

\subsection{Grape Pomace Powder Production and Natural Milk Starter Culture Preparation}

Grape pomace powder (GPP) was prepared from red grape pomaces of Nero d'Avola cultivar provided by the winemaking factory "Cantine Europa" located in Petrosino (TP, Sicily, Italy) following the methodology described by Marchiani et al. [7]. Grape pomaces were dried in the semi-industrial oven Compact Combi (Electrolux, Pordenone, Italy) at $54{ }^{\circ} \mathrm{C}$ for $48 \mathrm{~h}$ and milled through a Retsch apparatus (Haan, Germany) to a particle size of $250 \mu \mathrm{m}$.

Four different natural milk starter cultures (NMSCs) were developed with four strains, individually inoculated, of Lactococcus lactis (Mise36, Mise94, Mise169, and Mise190) belonging to the culture collection of the Department of Agricultural, Food, and Forest Sciences (University of Palermo, Italy). These strains were previously isolated from fermented raw ewes' milks added with the main grape polyphenols commonly found in winery by-products and selected as technologically relevant for dairy applications [15]. All strains were cultivated in M17 broth (Biotec, Grosseto, Italy) at $30{ }^{\circ} \mathrm{C}$ for $24 \mathrm{~h}$ and centrifuged at $10,000 \times g$ for $5 \mathrm{~min}$. The cells were then washed twice in Ringer's solution (Sigma-Aldrich, Milan, Italy) and re-suspended in the same solution. The washed cells of each LAB strain were singly inoculated $(1 \%, v / v)$ into $1 \mathrm{~L}$ of whole fat UHT milk (Conad, Mantova, Italy) and incubated at $30{ }^{\circ} \mathrm{C}$ for $24 \mathrm{~h}$ when they reached a concentration of approximately $10^{9}$ colony forming units $(\mathrm{CFU}) / \mathrm{mL}$, as ascertained by plate count. These fermented milks represented the four NMSCs to be used in cheese production. 


\subsection{Cheese Production and Sample Collection}

The experimental cheese making trials were carried out at a dairy pilot plant (Biopek, Gibellina, Italy) following the protocol of production for the stretched cheese "Vastedda" [16]. The experimental plan included two different cheese productions for each LAB strain for a total of eight trials: CP36, control production with L. lactis MISE36; EP36, experimental production with L. lactis MISE36 + 1\% of GPP; CP94, control production with L. lactis MISE94; EP94, experimental production with L. lactis MISE94 + 1\% of GPP; CP169, control production with L. lactis MISE169; EP169, experimental production with L. lactis MISE169 + $1 \%$ of GPP; CP190, control production with L. lactis MISE190; EP190, experimental production with L. lactis MISE190 + 1\% of GPP. Each trial was obtained with $20 \mathrm{~L}$ of pasteurized $\left(72{ }^{\circ} \mathrm{C}\right.$ for $15 \mathrm{~s}$ ) ewes' milk. Cheese productions were performed in plastic vats after sanitization with a solution of $2 \%(v / v)$ of $\mathrm{H}_{2} \mathrm{O}_{2}$ and acid adjuvant (PROMOX P900, Leggiuno, Italy) for $15 \mathrm{~min}$ to eliminate contaminant bacteria and fungi. Milk (cooled at $38^{\circ} \mathrm{C}$ ) was firstly inoculated with the corresponding NMSC $(200 \mathrm{~mL})$ to reach the final cell densities of $10^{7} \mathrm{CFU} / \mathrm{mL}$ and secondly added with $6 \mathrm{~mL}$ of liquid rennet (Fromase ${ }^{\circledR} 220 \mathrm{TL}$, DSM Bright Science Brighter Living, Heerlen, Netherlands). After coagulation, the curds were broken with a stainless-steel curd beater until small rice-size grains were obtained. After whey draining, the control curds were immediately put into perforated containers while the experimental curds were added with $1 \%(w / w)$ of GPP, which was manually mixed and then transferred into perforated containers. The $\mathrm{pH}$ of control and experimental curds was monitored electrometrically by means of the $\mathrm{pH}$-meter $\mathrm{pH} 70$ + DHS (XS Instruments, Carpi, Italy). When curd acidification reached $\mathrm{pH}$ values in the range 5.20-5.40, the curds were stretched under hot $\left(80-85^{\circ} \mathrm{C}\right)$ water and molded into a bun shape. The cheeses were salted in saturated brine for $30 \mathrm{~min}$, dried for $24 \mathrm{~h}$ at room temperature, packaged under vacuum, and kept under refrigeration $\left(5^{\circ} \mathrm{C}\right)$ for $15 \mathrm{~d}$. All cheese trials were carried out in duplicate in two consecutive weeks. The sampling points, the number of samples analyzed, and the analyses performed are reported in Table 1.

Table 1. Sampling points ${ }^{\mathrm{a}}$ and analyses performed during cheese production.

\begin{tabular}{|c|c|c|c|c|c|c|c|c|c|c|c|}
\hline \multirow[t]{3}{*}{ Analyses } & \multicolumn{11}{|c|}{ Sampling Points } \\
\hline & \multirow[t]{2}{*}{ BM } & \multirow[t]{2}{*}{ PBM } & \multirow[t]{2}{*}{ IM } & \multicolumn{2}{|c|}{ Curd $t_{0}$} & \multicolumn{2}{|c|}{$\begin{array}{l}\text { Acidified } \\
\text { Curds }\end{array}$} & \multicolumn{2}{|c|}{ Cheese at $t_{0}$} & \multicolumn{2}{|c|}{ Cheese at $15 \mathrm{~d}$} \\
\hline & & & & Ctr & Exp & Ctr & $\operatorname{Exp}$ & Ctr & $\operatorname{Exp}$ & Ctr & Exp \\
\hline $\begin{array}{c}\text { pH } \\
\text { plate counts } \\
\text { molecular typing } \\
\text { physical aspects } \\
\text { chemical composition } \\
\text { VOCs } \\
\text { sensory tests } \\
\text { functional properties }\end{array}$ & $\begin{array}{l}\square \\
\square\end{array}$ & $\begin{array}{l}\square \\
\square \\
\square\end{array}$ & $\square$ & $\begin{array}{l}\mathbf{\square} \\
\mathbf{\square}\end{array}$ & $\begin{array}{l}\square \\
\square \\
\square\end{array}$ & $\begin{array}{l}\boldsymbol{\square} \\
\boldsymbol{\square}\end{array}$ & $\begin{array}{l}\mathbf{\square} \\
\mathbf{\square} \\
\mathbf{\square}\end{array}$ & 口 & 口 & $\begin{array}{l}\mathbf{a} \\
\mathbf{\square} \\
\mathbf{0} \\
\mathbf{\square} \\
\mathbf{\square} \\
\mathbf{\square}\end{array}$ & $\begin{array}{l}\mathbf{\square} \\
\mathbf{\square} \\
\mathbf{\square} \\
\mathbf{\square} \\
\mathbf{\square} \\
\mathbf{\square}\end{array}$ \\
\hline
\end{tabular}

a Two samples were analyzed for each production. Abbreviations: BM, bulk milk; PBM, pasteurized bulk milk before inoculum; IM, inoculated milk with Natural Milk starter cultures (NMSCs); Ctr, control; Exp, experimental; VOCs, volatile organic compounds.

\subsection{Microbiological Analyses}

Cell suspensions of milk samples were directly subjected to decimal serial dilutions in Ringer's solution, while GPP, curd and cheese samples (15 g) were first homogenized with Ringer's solution $(135 \mathrm{~mL}$ ) by the stomacher Bag-Mixer 400 (Interscience, Saint Nom, France) for 2 min at the maximum speed (blending power 4) and then 1:10 serially diluted.

Cell suspensions of GPP were used to enumerate the following microbial groups: Total mesophilic microorganisms (TMM) on plate count agar (PCA), after incubation at $30^{\circ} \mathrm{C}$ for $72 \mathrm{~h}$; LAB rods and cocci on de Man-Rogosa-Sharpe (MRS) agar and M17 agar, respectively, both incubated at $30^{\circ} \mathrm{C}$ for $48 \mathrm{~h}$ in anaerobiosis; members of the Enterobacteriaceae family, detected on violet red bile glucose agar (VRBGA), after incubation at $37{ }^{\circ} \mathrm{C}$ for $24 \mathrm{~h}$; 
yeasts on dichloran rose bengal chloramphenicol (DRBC) agar, incubated at $28{ }^{\circ} \mathrm{C}$ for $24 \mathrm{~h}$; coagulase-positive and coagulase-negative staphylococci (CPS and CNS, respectively) on Baird Parker (BP) agar added with rabbit plasma fibrinogen, incubated at $37^{\circ} \mathrm{C}$ for $48 \mathrm{~h}$; Listeria monocytogenes on Listeria selective agar base (LSAB) added with SR0140E supplement, incubated at $37^{\circ} \mathrm{C}$ for $48 \mathrm{~h}$; Escherichia coli and Salmonella spp., detected on Hektoen enteric agar (HEA), incubated at $37^{\circ} \mathrm{C}$ for $24 \mathrm{~h}$. Anaerobiosis occurred in hermetically sealed jars added with the AnaeroGen AN25 system (Oxoid, Milan, Italy).

Cell suspensions of raw milk and pasteurized milk were subjected to plate count for the enumeration of TMM on Skim milk agar (SMA) ISO 6610 [17] incubated aerobically at $30^{\circ} \mathrm{C}$ for $72 \mathrm{~h}$; mesophilic rod-shaped LAB on MRS agar, acidified to $\mathrm{pH} 5.4$ with lactic acid $(5 \mathrm{~mol} / \mathrm{L})$ and incubated anaerobically for $48 \mathrm{~h}$ at $30^{\circ} \mathrm{C}$; thermophilic LAB rods were pour plated on whey-based agar medium (WBAM) prepared as described by Settanni et al. [18]; mesophilic and thermophilic coccus-shaped LAB on M17 agar, incubated anaerobically for $48 \mathrm{~h}$ at 30 and $44^{\circ} \mathrm{C}$, respectively.

Milk inoculated with each NMSC, curd and cheese samples were analyzed only for TMM and L. lactis on SMA and M17 agar, respectively. The last media were incubated as reported above.

All media and supplements were purchased from Biotec, except HEA provided by Microbiol Diagnostici (Uta, Italy). Plates counts were performed in duplicate.

\subsection{Persistence of Added Strains and Identification of the Survival Indigenous Milk LAB}

The persistence of the strains added as starter cultures and their dominance over the indigenous milk LAB resistant to pasteurization process was performed by randomly amplified polymorphic DNA (RAPD)-PCR technique as reported by Alfonzo et al. [19]. The colonies developed from the highest dilutions on the agar media used for LAB counts were randomly picked up, purified by successive sub-culturing, and tested for Gram reaction and catalase activity [20]. The presumptive LAB cultures, grown overnight, were subjected to DNA extraction using the DNA-SORB-B kit (Sacace Biotechnologies Srl, Como, Italy) following the protocol provided by the manufacturer. RAPD-PCR was performed by means of Swift ${ }^{\mathrm{TM}}$ MaxPro Thermal Cycler (Esco Health Care Pte. Ltd., Singapore) and the amplicons were separated by electrophoresis. The recognition of the added strains was performed by comparing the polymorphic profiles obtained from the isolates of a given trial with that of the pure culture added using the software Gelcompare II version 6.5 (Applied-Maths, Sin Marten Latem, Belgium).

The identification of the different LAB strains isolated from pasteurized bulk milk before NMSC inoculation was carried out by 16S rRNA gene sequencing as reported by Weisburg et al. [21]. The resulting DNA fragments were purified and sequenced by Eurofins Genomics (Ebersberg, Germany). The sequences were compared with the sequences available in GenBank/EMBL/DDBJ (http://www.ncbi.nlm.nih.gov) and EzTaxon-e (http:/ / eztaxon-e.ezbiocloud.net/) databases.

\subsection{Physicochemical Analyses of Cheeses}

Cheeses after $15 \mathrm{~d}$ of refrigerate storage were assessed for external and internal color, measured in duplicate by a Minolta Chroma Meter CR300 (Minolta, Osaka, Japan) using the illuminant $C$; results are expressed as lightness $\left(L^{*}\right.$, from $0=$ black, to $100=$ white), redness $\left(a^{*}\right.$, from red $=+a$, to green $\left.=-a\right)$, and yellowness $\left(b^{*}\right.$, from yellow $=+b$, to blue $=-b)$, according to the CIE $L^{*} a^{*} b^{*}$ system. Cheese hardness was evaluated with an Instron 5564 tester (Instron, Trezzano sul Naviglio, Milan, Italy) measuring the maximum resistance to compression (compressive stress, $\mathrm{N} / \mathrm{mm}^{2}$ ) of samples $(2 \mathrm{~cm} \times 2 \mathrm{~cm} \times 2 \mathrm{~cm}$ ) kept at room temperature $\left(22^{\circ} \mathrm{C}\right)$.

Cheese samples were freeze-dried and analyzed using standard methods of the International Dairy Federation for dry matter (DM) (IDF, 4A:1982) [22], fat (IDF, 5B:1986) [23], protein $(\mathrm{N} \times 6.38)(\mathrm{IDF}, 25: 1964 \mathrm{a})$ [24], and ash (IDF, 27:1964b) [25] content. In addition, the products of secondary lipid oxidation were assessed in duplicate on freeze-dried sam- 
ples by determining the thiobarbituric acid-reactive substances (TBARs), expressed as $\mu \mathrm{g}$ malonylaldehyde (MDA)/kg DM, as described by Bonanno et al. [26].

\subsection{Volatile Organic Compounds}

Five grams of the final cheese samples were finely chopped and placed into $25 \mathrm{~mL}$ glass vials sealed with silicon septum. The headspace solid phase microextraction SPME (DVB/CAR/PDMS, $50 \mathrm{~mm}$, Supelco) fiber was exposed to the cheese under continuous stirring at $60{ }^{\circ} \mathrm{C}$ for $15 \mathrm{~min}$. After sampling, the SPME fiber was thermally desorbed for $1 \mathrm{~min}$ through a splitless GC injector at $250{ }^{\circ} \mathrm{C}$. A gas chromatograph (Agilent 6890) equipped with a mass selective detector (Agilent $5975 \mathrm{c}$ ) and a DB-624 capillary column (Agilent Technologies, $60 \mathrm{~m}, 0.25 \mathrm{~mm}, 1.40 \mu \mathrm{m}$ ) was used for the chromatographic analysis. Chromatographic conditions applied were helium carrier gas at $1 \mathrm{~mL} / \mathrm{min}$ and an oven temperature program with a $5 \mathrm{~min}$ isotherm at $40{ }^{\circ} \mathrm{C}$ followed by a linear temperature increase of $5{ }^{\circ} \mathrm{C}$ min up to $200{ }^{\circ} \mathrm{C}$, where it was held for $2 \mathrm{~min}$. The MS scan conditions were interface temperature was $230^{\circ} \mathrm{C}$ acquisition mass range was 40-400; acquisition mode was scan. The volatile organic compounds were also determined for GPP.

The identification of VOC compounds was performed through the comparison of the MS spectra with commercial library NIST05. The relative proportions of the identified constituents were expressed as percentages obtained by GC-MS peak area normalization with total area of significant peaks. Three replicates of each sample were analyzed.

\subsection{Sensory Evaluation}

The cheeses were also evaluated for their sensory traits. All cheeses were judged by 12 assessor members including 6 men and 6 women (aged between 21-65 years old) familiar with the sensory analysis of cheese. All panelists were specifically trained for cheese attribute evaluation following the ISO 8589 [27] indications. The cheeses were acclimated at about $20^{\circ} \mathrm{C}$ for $1 \mathrm{~h}$, cut into cubes $(3 \mathrm{~cm} \times 3 \mathrm{~cm} \times 3 \mathrm{~cm})$ and then coded and served in a random order. Twelve descriptive attributes were judged as evaluated by Costa et al. [28]. In particular, for each cheese, the evaluation considered the following aspects: Intensity of odor and aroma, sweet, salt, bitter, acid, fiber, friability, adhesiveness, hardness, humidity, and the overall assessment. Each aspect was scored using a line scale from 0 to $7(\mathrm{~cm})$ as reported by Faccia et al. [29].

\subsection{In Vitro Gastrointestinal Digestion}

Simulated in vitro human digestion, mimicking physicochemical and biochemical changes of the food in the upper gastrointestinal (GI) tract, was performed $(n=3)$ as reported by Attanzio et al. [30]. Samples of $7.5 \mathrm{~g}$ of cheese were added in $20 \mathrm{~mL}$ of a buffered pH 6.8 solution simulating saliva [ $\mathrm{NaCl}(0.126 \mathrm{~g}), \mathrm{KC} 1(0.964 \mathrm{~g}) \mathrm{KSCN}(0.189 \mathrm{~g})$, $\mathrm{KH}_{2} \mathrm{PO}_{4}(0.655 \mathrm{~g})$, urea $(0.200 \mathrm{~g}), \mathrm{Na}_{2} \mathrm{SO}_{4} \cdot 10 \mathrm{H}_{2} \mathrm{O}(0.763 \mathrm{~g}), \mathrm{NH}_{4} \mathrm{Cl}(0.178 \mathrm{~g}), \mathrm{CaCl}_{2} \cdot 2 \mathrm{H}_{2} \mathrm{O}$ $(0.228 \mathrm{~g})$, and $\mathrm{NaHCO}_{3}(0.631 \mathrm{~g})$ in $1 \mathrm{~L}$ of distilled water]. The mixture was blended for 3 times $\times 15 \mathrm{~s}$ in a semi-micro stainless-steel blender jar using a Waring blender (Waring, New Hartford, CT, USA) miming the oral phase of digestion. Post-oral samples were then transferred into a bottle, acidified at $\mathrm{pH}=2.0$ with $\mathrm{HCl}$ before porcine pepsine addition (8 mg/mL; 3200-4500 units/mg, Sigma-Aldrich). The bottle was sealed and incubated in a water bath (type M 428-BD, Instruments s.r.1., Bernaggio, Mi, Italy) with shaking (100 rpm), at $37^{\circ} \mathrm{C}$ for $2 \mathrm{~h}$, in the dark. Post-gastric digested were brought to a final $\mathrm{pH} 7.5$ adding $200 \mathrm{mM} \mathrm{NaH}_{2} \mathrm{PO}_{4} / \mathrm{Na}_{2} \mathrm{HPO}_{4}$ buffer and $5 \mathrm{M} \mathrm{NaOH}$. Then porcine bile extract $(2.4 \mathrm{mg} / \mathrm{mL}$, Sigma) and pancreatin from hog pancreas $(0.4 \mathrm{mg} / \mathrm{mL}$, Sigma) were added. The bottle was sealed and incubated in the shaking water bath at $37^{\circ} \mathrm{C}$ for $2 \mathrm{~h}$, in the dark. The digestion was stopped by ice bath immersion. Post-intestinal digested was centrifuged at $167,000 \times$ $g$ for 35 min at $4{ }^{\circ} \mathrm{C}$ (Beckman Optima TLX ultracentrifuge, Beckman Instruments, Inc., Palo Alto, CA, USA) to separate supernatant (Bioaccesible fraction) from the particulate material. Aliquots of samples from each digestion step were withdrawn and centrifuged at 
$1500 \times g$ for $10 \mathrm{~min}$ at $4{ }^{\circ} \mathrm{C}$. Supernatants and bioaccesible fraction were brought at $\mathrm{pH} 2.0$ to stabilize polyphenols and stored at $-80^{\circ} \mathrm{C}$ until analysis.

\subsection{ABTS $^{+}$Radical Cation Decolorization Assay}

Radical scavenging activity was evaluated using the ABTS ${ }^{+}$radical cation decolorization assay as described by Attanzio et al. [31]. Samples were analyzed in duplicate, at three different dilutions, within the linearity range of the assay. The assay was standardized with the water-soluble vitamin E analog Trolox (Sigma), and results were expressed as $\mu \mathrm{mol}$ Trolox equivalents/g cheese.

\subsection{Lipid Peroxidation Assay}

Pig's brain microsomes were prepared from a tissue homogenate in $10 \mathrm{mM}$ phosphate buffer saline, pH 7.4 (PBS), by differential centrifugation. Microsomes in PBS (2 mg protein $/ \mathrm{mL}$ ) were pre-incubated for $5 \mathrm{~min}$ at $37^{\circ} \mathrm{C}$ either in the absence (control) or in the presence of variable amounts of the bioaccessible fraction of cheeses. Lipid oxidation

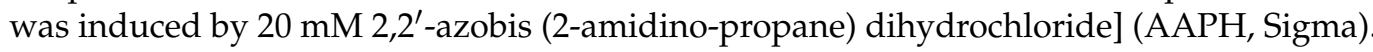
Lipid hydroperoxides formation was monitored after reaction with thiobarbituric acid (TBA), as TBA-reactive substances (TBARS). Aliquots $(1 \mathrm{~mL})$ of the reaction mixture were added to $2 \mathrm{~mL}$ of a solution containing 15\% TCA $(v / v), 0.375 \%$ TBA $(w / v), 0.25 \mathrm{~N} \mathrm{HCl}$, and $0.02 \%$ BHT $(w / v)$, to prevent formation of non-specific TBA-RS and decomposition of AAPH during the subsequent boiling. The mixture was incubated in a boiling water bath for $30 \mathrm{~min}$. After cooling, samples were clarified by centrifugation, and TBA-RS in the supernatant determined at $532 \mathrm{~nm}$. The results are expressed as nmol of MDA equiv/mg of protein, using the molar extinction coefficient of 156,000.

Proteins in microsomal preparations were determined by the Bio Rad colorimetric method [32].

\subsection{Statistical Analyses}

Data of microbiological analyses and physicochemical traits of $15 \mathrm{~d}$ cheeses were statistically analyzed using the generalized linear model (GLM) procedure in SAS 9.2 (SAS, 2010) to evaluate the effects of cheese trial $(1,2)$, treatment (TR) with grape pomace powder (control, experimental), starter culture (NMSC: Mise36, Mise94, Mise169, Mise190) and the interaction TR*NMSC. When a statistically significant effect $(p \leq 0.05)$ of NMSC and TR*NMSC interaction was detected, means were compared using $p$-values adjusted according to the Tukey-Kramer multiple comparisons test. The results of in vitro digestion of cheeses were made using one-way ANOVA test, with Tukey's correction for multiple comparisons by Instat-3 statistical software (GraphPad Software Inc., San Diego, CA, USA). Comparison between individual group means was performed by unpaired Student's $t$-test. In all cases, significance was accepted if the null hypothesis was rejected at the $p<0.05$.

\section{Results and Discussion}

\subsection{Acidification Kinetics of Curds}

The evolution of curd $\mathrm{pH}$ is shown in Figure 1. Statistically significant differences were found between control and experimental curds for all strains inoculated. The initial values of $\mathrm{pH}$ of control curds were at ca. 6.7, while lower values (ca. 6.4) were registered for the experimental curds. These differences $(p<0.0001)$ were registered until the end of the acidification process.

The lower values of $\mathrm{pH}$ in experimental curds are imputable to the presence of organic acids such as tartaric acid, malic acid, and citric acid in GPP [7]. However, all curds reached the value comprised in the range 5.20-5.40, which represents the optimum level of acidity allowing the stretching of the curd [33], about $24 \mathrm{~h}$ after curdling (Figure 2). 


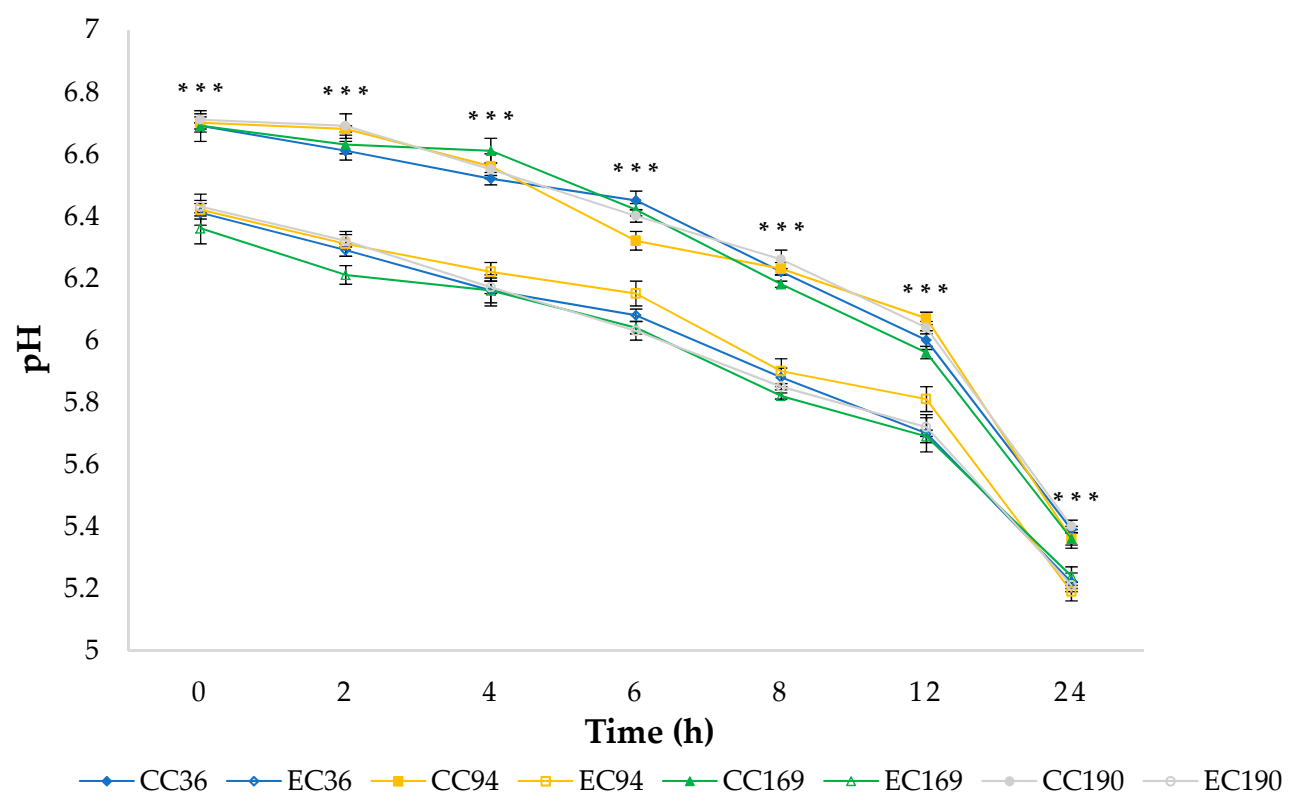

Figure 1. Acidification kinetics of curds. Full symbols: Control curds. Empty symbols: Experimental curds. Results indicate mean values \pm SD of four determinations (carried out in duplicate for two independent productions). In comparison with the corresponding result of grape pomace powder (GPP)-enriched curd, values are significant with *** $p<0.0001$. Abbreviations: CC36, CC94, CC169, and CC190, control curd with L. lactis MISE36, MISE94, MISE169, and MISE190, respectively; EC36, EC94, EC169, and EC190, experimental curd with 1\% of GPP and L. lactis MISE36, MISE94, MISE169, and MISE190, respectively. Bars represent standard deviation of the mean.

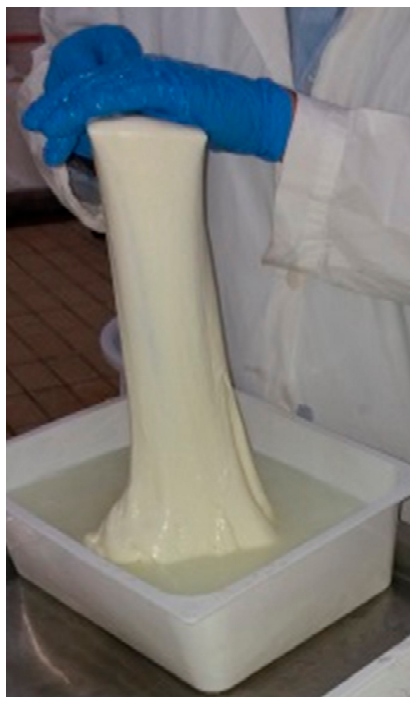

(a)

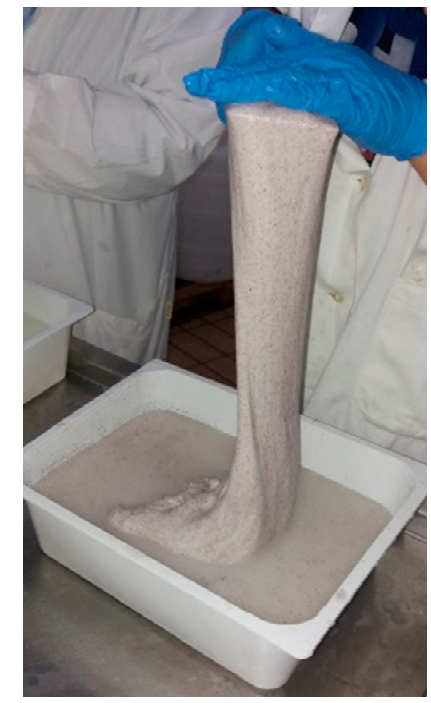

(b)

Figure 2. Stretching step of the acidified curds. (a) Control cheese production; (b) GPP-enriched cheese production.

\subsection{Microbiological Analyses}

The microbiological loads of the samples collected during the cheese-making trials are reported in Table 2. The microbiological analyses of GPP did not evidence the presence of any of the microbial groups object of investigation. The absence of microorganisms in GPP is undoubtedly due to the oven-drying stabilization [34]. Raw ewes' milk hosted levels of TMM of 6.51 Log CFU/mL, higher than the limit $\left(<10^{5} \mathrm{CFU} / \mathrm{mL}\right)$ established in Europe for 
raw ewes' milk for cheese production, with mesophilic rod and coccus $\mathrm{LAB}$ at $10^{6} \mathrm{CFU} / \mathrm{mL}$ and thermophilic rod and coccus LAB at $10^{4} \mathrm{CFU} / \mathrm{mL}$. The high levels probably depend on the conservation conditions [35]. After pasteurization, TMM, thermophilic rod, and coccus $\mathrm{LAB}$ were recorded at $10^{3} \mathrm{CFU} / \mathrm{mL}$, while mesophilic rod and coccus $\mathrm{LAB}$ were lower than $10^{2} \mathrm{CFU} / \mathrm{mL}$, showing the ability of the indigenous thermoduric LAB to survive during the thermal treatment [36]. However, the effect of pasteurization depends on the initial cell densities of microorganisms in the raw milk [37] and the temperatures applied [38]. According to Tukey's test, statistically significant differences were found only for the levels of TMM in curd samples. The levels of TMM were almost superimposable to those of mesophilic coccus LAB in all samples analyzed. After inoculation with each NMSC, all milks showed approximately 7 Log cycles of TMM and almost the same levels of mesophilic coccus $\mathrm{LAB}$, confirming that the inoculums occurred at $10^{7} \mathrm{CFU} / \mathrm{mL}$ and the starter $\mathrm{LAB}$ cocci dominated the microbial community of cheeses. After coagulation, an increase of about 1 Log cycle was registered for the LAB levels in all control and experimental curds as a consequence of whey draining [39]. The levels of TMM and mesophilic coccus LAB reached values of about $9 \log \mathrm{CFU} / \mathrm{g}$ in all acidified curds and these levels remained almost constant in control and experimental cheeses soon after production as well as after $15 \mathrm{~d}$ of refrigerated storage as previously observed by Gaglio et al. [40,41] during the production of Vastedda della valle del Belice PDO cheeses. The results highlighted that the addition of $1 \%(w / w)$ of GPP did not influence the fermentation process carried out by the four L. lactis (Mise36, Mise94, Mise169, and Mise190) strains used individually.

Table 2. Microbial evolution ${ }^{\text {a }}$ during experimental cheese productions.

\begin{tabular}{|c|c|c|c|c|c|c|c|c|c|c|c|}
\hline & & \multirow{2}{*}{\multicolumn{2}{|c|}{ Treatment (TR) }} & \multicolumn{4}{|c|}{ Natural Milk Starter Culture (NMSC) } & \multirow[b]{2}{*}{ SEM } & \multicolumn{3}{|c|}{ Significance $p<$} \\
\hline & & & & MISE36 & MISE94 & MISE169 & MISE190 & & TR & NMSC & TR*NMSC \\
\hline $\begin{array}{l}\text { Inoculated } \\
\text { milk }\end{array}$ & TMM & & & $7.23 \mathrm{ab}$ & $7.33 \mathrm{a}$ & $6.94 \mathrm{ab}$ & $7.08 \mathrm{~b}$ & 0.088 & & 0.0442 & \\
\hline \multirow[t]{2}{*}{ Curd $t_{0}$} & $\begin{array}{c}\text { MCLAB } \\
\text { TMM }\end{array}$ & $\begin{array}{l}\text { Ctr } \\
\text { Exp } \\
\text { Tot }\end{array}$ & $\begin{array}{l}7.93 \\
7.75\end{array}$ & $\begin{array}{c}7.30 \\
8.12 \\
7.99 \\
8.06 \mathrm{a}\end{array}$ & $\begin{array}{c}6.95 \\
7.98 \\
7.71 \\
7.84 \mathrm{ab}\end{array}$ & $\begin{array}{c}7.04 \\
7.83 \\
7.61 \\
7.72 \mathrm{~b}\end{array}$ & $\begin{array}{c}7.18 \\
7.77 \\
7.71 \\
7.74 \mathrm{~b}\end{array}$ & $\begin{array}{l}0.14 \\
0.10\end{array}$ & 0.0227 & $\begin{array}{l}0.3546 \\
0.0096\end{array}$ & 0.7364 \\
\hline & MCLAB & $\begin{array}{l}\text { Ctr } \\
\text { Exp } \\
\text { Tot }\end{array}$ & $\begin{array}{l}7.77 \\
7.74\end{array}$ & $\begin{array}{l}7.89 \\
7.78 \\
7.83\end{array}$ & $\begin{array}{l}7.81 \\
7.89 \\
7.85\end{array}$ & $\begin{array}{l}7.74 \\
7.60 \\
7.67\end{array}$ & $\begin{array}{l}7.63 \\
7.70 \\
7.66\end{array}$ & 0.13 & 0.7777 & 0.3440 & 0.7577 \\
\hline \multirow{2}{*}{$\begin{array}{l}\text { Acidified } \\
\text { curd }\end{array}$} & TMM & Ctr & 9.13 & 9.01 & 9.23 & 9.15 & 9.14 & 0.12 & 0.7408 & 0.2539 & 0.8490 \\
\hline & MCLAB & $\begin{array}{l}\text { Exp } \\
\text { Tot } \\
\text { Ctr } \\
\text { Exp } \\
\text { Tot }\end{array}$ & $\begin{array}{l}9.16 \\
\\
9.44 \\
9.48\end{array}$ & $\begin{array}{l}9.07 \\
9.04 \\
9.47 \\
9.38 \\
9.42\end{array}$ & $\begin{array}{l}9.33 \\
9.28 \\
9.35 \\
9.53 \\
9.44\end{array}$ & $\begin{array}{l}9.20 \\
9.18 \\
9.44 \\
9.69 \\
9.57\end{array}$ & $\begin{array}{l}9.04 \\
9.09 \\
9.49 \\
9.30 \\
9.39\end{array}$ & 0.10 & 0.5935 & 0.3304 & 0.1127 \\
\hline \multirow[t]{2}{*}{$\begin{array}{c}\text { Cheese } \\
\text { at } t_{0}\end{array}$} & $\mathrm{TMM}$ & Ctr & 8.66 & 8.66 & 8.63 & 8.69 & 8.66 & 0.13 & 0.3307 & 0.9658 & 0.9431 \\
\hline & MCLAB & $\begin{array}{l}\text { Exp } \\
\text { Tot } \\
\text { Ctr } \\
\text { Exp } \\
\text { Tot }\end{array}$ & $\begin{array}{l}8.57 \\
\\
8.62 \\
8.60\end{array}$ & $\begin{array}{l}8.57 \\
8.62 \\
8.70 \\
8.61 \\
8.65\end{array}$ & $\begin{array}{l}8.55 \\
8.59 \\
8.52 \\
8.56 \\
8.54\end{array}$ & $\begin{array}{l}8.50 \\
8.59 \\
8.77 \\
8.65 \\
8.71\end{array}$ & $\begin{array}{l}8.64 \\
8.65 \\
8.49 \\
8.57 \\
8.53\end{array}$ & 0.13 & 0.8256 & 0.4783 & 0.8644 \\
\hline \multirow{2}{*}{$\begin{array}{c}\text { Cheese } \\
\text { at } t_{15}\end{array}$} & TMM & Ctr & 8.73 & 8.62 & 8.98 & 8.60 & 8.71 & 0.075 & 0.8795 & 0.0074 & 0.2972 \\
\hline & MCLAB & $\begin{array}{l}\text { Exp } \\
\text { Tot } \\
\text { Ctr } \\
\text { Exp } \\
\text { Tot }\end{array}$ & $\begin{array}{l}8.74 \\
\\
8.76 \\
8.75\end{array}$ & $\begin{array}{c}8.72 \\
8.67 \mathrm{~b} \\
8.70 \\
8.77 \\
8.73\end{array}$ & $\begin{array}{c}8.81 \\
8.89 \mathrm{a} \\
8.89 \\
8.74 \\
8.82\end{array}$ & $\begin{array}{c}8.63 \\
8.62 \mathrm{~b} \\
8.69 \\
8.75 \\
8.72\end{array}$ & $\begin{array}{c}8.79 \\
8.75 \mathrm{ab} \\
8.76 \\
8.74 \\
8.75\end{array}$ & 0.071 & 0.8147 & 0.5271 & 0.3911 \\
\hline
\end{tabular}

${ }^{\text {a }}$ Units are $\log \mathrm{CFU} / \mathrm{mL}$ for liquid samples and $\log \mathrm{CFU} / \mathrm{g}$ for solid samples. Results indicate mean values of four plate counts (carried out in duplicate for two independent productions). On the row: $\mathrm{a}, \mathrm{b}=p<0.05$. Abbreviations: SEM, standard error of means of interaction; TMM, total mesophilic microorganisms; MCLAB, mesophilic coccus lactic acid bacteria; Ctr, control; Exp, experimental; Tot, total.

\subsection{Persistence of LAB Inoculums}

Three hundred and ninety-six colonies of presumptive LAB were isolated during cheese making, from pasteurized bulk milk until stored cheeses. After Gram and catalase tests, 360 Gram-positive and catalase-negative cultures were still considered presumptive LAB cultures. The determination of starter persistence by means of RAPD patterns comparison is a common technique to monitor the dynamics of the added strains and their 
dominance over indigenous bacteria during cheese productions [33,40]. Figure 3 shows the dendrogram with only 44 of the $360 \mathrm{LAB}$ strains analyzed, which are those isolated at least once from the different samples.

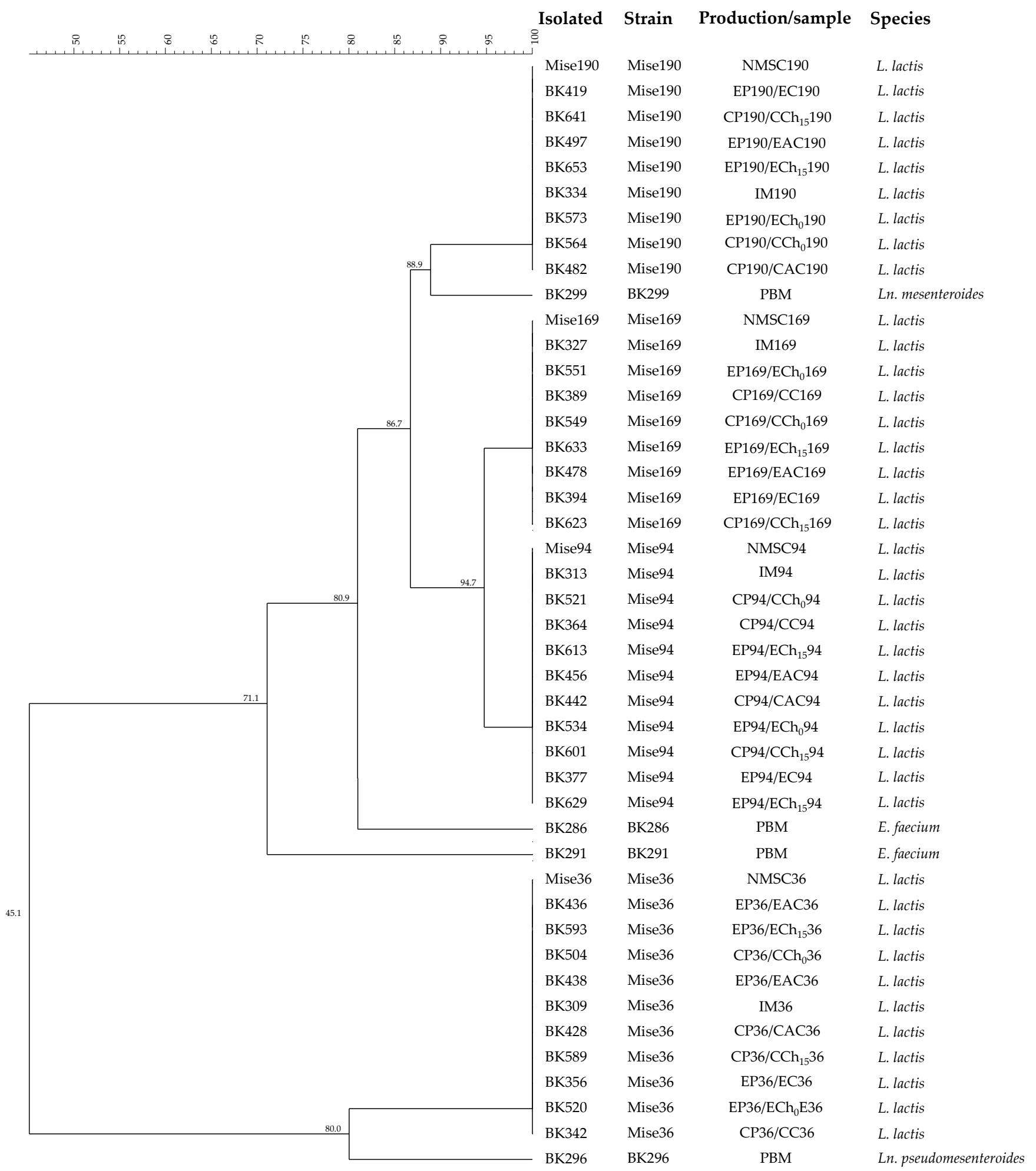

Figure 3. Dendrogram obtained with combined randomly amplified polymorphic DNA (RAPD)-PCR patterns generated with three primers for lactic acid bacteria (LAB) strains isolated during cheese productions. The line at the top indicates percentages of similarity. Abbreviations: L., Lactococcus; E., Enterococcus; Ln., Leuconostoc; BK, Biopek dairy factory; CP, control 
production; EP, experimental production; IM36, IM94, IM169, and IM190, inoculated milk with L. lactis MISE36, MISE94, MISE169, and MISE190, respectively; CC36, CC94, CC169, and CC190, control curd with L. lactis MISE36, MISE94, MISE169, and MISE190, respectively; EC36, EC94, EC169, and EC190, experimental curd with 1\% of GPP and L. lactis MISE36, MISE94, MISE169, and MISE190, respectively; CAC36, CAC94, CAC169, and CAC190, control acidified curd with L. lactis MISE36, MISE94, MISE169, and MISE190, respectively; EAC36, EAC94, EAC169, and EAC190, experimental acidified curd with 1\% of GPP and L. lactis MISE36, MISE94, MISE169, and MISE190, respectively; CCh $36, \mathrm{CCh}_{0} 94, \mathrm{CCh}_{0} 169$, and CCh 190 , control cheese with L. lactis MISE36; MISE94, MISE169, and MISE190, respectively; ECh $36, \mathrm{ECh}_{0} 94, \mathrm{ECh}_{0} 169$, and ECh 190 experimental cheese with 1\% of GPP and L. lactis MISE36, MISE94, MISE169, and MISE190, respectively; CCh 15 36, CCh 94 , $\mathrm{CCh}_{15} 169$, and $\mathrm{CCh}_{15} 190$, control cheese after $15 \mathrm{~d}$ of refrigerate storage with L. lactis MISE36; MISE94, MISE169, and MISE190, respectively; $\mathrm{ECh}_{15} 36, \mathrm{ECh}_{15} 94, \mathrm{ECh}_{15} 169$, and $\mathrm{ECh}_{15} 190$ experimental cheese after $15 \mathrm{~d}$ of refrigerate storage with 1\% of GPP and L. lactis MISE36, MISE94, MISE169, and MISE190, respectively; PBM, pasteurized bulk milk before inoculum.

Four major RAPD clusters were identified. Each cluster included one L. lactis strain used for the preparation of the NMSCs. Four LAB strains (BK286, BK291, BK296, and BK299) collected from pasteurized bulk milk before inoculum were subjected to the $16 S$ rRNA gene sequencing and identified as Enteroccus faecium (Ac. No. MW283889MW283890), Leuconostoc mesenteroides (Ac. No. MW283891) and Leuconostoc pseudomesenteroides (Ac. No. MW283892). These species are part of the common dairy starter LAB and non-starter LAB cultures [42]. However, these strains were not detected in any of the samples analyzed after milk inoculation with NMSCs, highlighting the dominance of the selected L. lactis strains (Mise36, Mise94, Mise169 and Mise190) over the indigenous thermoduric milk LAB (Figure 2).

\subsection{Physicochemical Analyses of Cheeses}

The physicochemical parameters of the final cheeses are reported in the Table 3. As expected, the inclusion of GPP modified markedly both external and internal color indexes. Indeed, the experimental cheeses acquired an evident pink color, as indicated by the strong redness increase, to which corresponded the reduction of lightness and yellowness, whereas the indexes recorded on control cheeses were in line with those reported for ovine stretched cheeses by Todaro et al. [43].

The chemical composition of cheeses was affected by both GPP inclusion and the starter cultures. GPP are characterized by lower lipid content than milk determining a decrease of fat and, consequently, an increase of protein in GPP-enriched cheeses. The increase of ash can be referred to the higher ash level of GPP compared to milk. Similar trends for lipid, protein, and ash concentrations were observed by Marchiani et al. [7] in cheeses fortified with GPP of different origin. Regarding the starter strains, a different behavior was observed for L. lactis MISE94 and MISE190 that in experimental cheeses induced a stronger fat decrease, which was accompanied by a protein increase, suggesting a more intense recourse to fatty acids to sustain their energy metabolism [44]. Nevertheless, the levels recorded for each chemical component were within the ranges observed in other investigations for Vastedda cheeses [43].

GPP inclusion was also responsible for the hardness increase of the cheese paste, evaluated as resistance to compression, presumably due to the effect of GPP in increasing DM or lowering fat content in experimental cheeses; however, in accordance to the results of sensory evaluation, the difference for hardness was almost negligible when the strain L. lactis MISE36 strain was used, an aspect that can be referred to the lower difference in fat content together with a similar DM level between the corresponding control and GPP-enriched cheeses.

Moreover, higher TBARS values were observed in experimental rather than control cheeses, indicating that the presence of GPP did not inhibit the lipid oxidation, despite their interesting content in phenolic compounds with antioxidant activity $[7,44]$. Since the experimental cheeses were lower in fat, this higher presence of oxidation products could be linked to their enrichment with the polyunsaturated fatty acids that characterizes the lipid profile of GPP [44] and are more sensitive to oxidation. 
Table 3. Physicochemical traits of cheeses after $15 \mathrm{~d}$ of refrigerated storage.

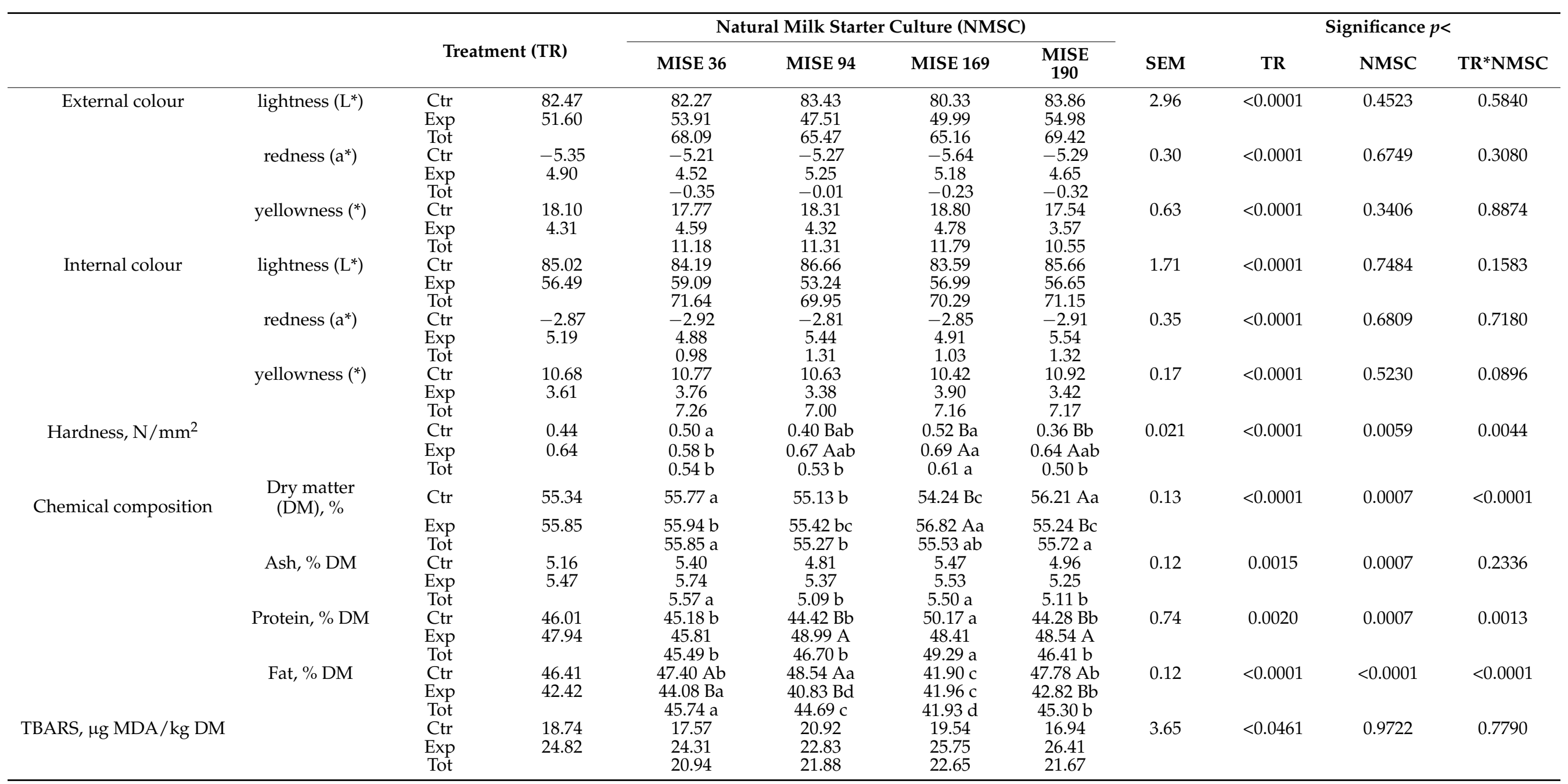

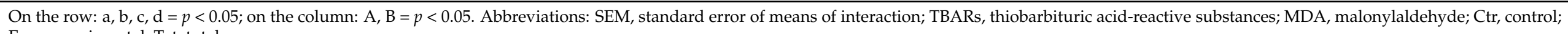
Exp, experimental; Tot, total. 


\subsection{Volatile Organic Compounds}

Volatile profiles are generated by complex biochemical processes derived from the hydrolysis or metabolism of carbohydrates, proteins, and fats, along with compounds added during processing or directly from the milk due to the activity of LAB [45]. VOCs were identified in cheese samples and GPP by SPME-GC/MS technique (Table 4).

Table 4. Volatile organic compounds emitted from cheeses.

\begin{tabular}{|c|c|c|c|c|c|c|c|c|c|}
\hline \multirow{2}{*}{ Chemical Compounds ${ }^{a}$} & \multicolumn{9}{|c|}{ Samples } \\
\hline & GPP & $\mathrm{CCh}_{15} 36$ & $\mathrm{ECh}_{15} 36$ & $\mathrm{CCh}_{15} 94$ & $\mathrm{ECh}_{15} 94$ & $\mathrm{CCh}_{15} 169$ & $\mathrm{ECh}_{15} 169$ & $\mathrm{CCh}_{15} 190$ & $\mathrm{ECh}_{15} 190$ \\
\hline Acids & & & & & & & & & \\
\hline Acetic acid & n.d. & 9.5 & 16.2 & 14.1 & 14.9 & 9.2 & 11.8 & 18.7 & 10.4 \\
\hline Butanoic acid & n.d. & 9.2 & 7.5 & 10.9 & 7.4 & 5.7 & 5.7 & 9.0 & 6.0 \\
\hline 4-Hydroxybutanoic acid & 4.1 & n.d. & n.d. & n.d. & n.d. & n.d. & n.d. & n.d. & n.d. \\
\hline Hexanoic acid & 1.6 & 5.9 & 5.0 & 8.2 & 4.3 & 4.3 & 4.0 & 7.1 & 4.3 \\
\hline $\begin{array}{c}\text { Pentanoinc } \\
\text { acid-2-hydroxy-4-methyl }\end{array}$ & n.d. & 16.0 & 2.5 & 12.2 & 7.2 & 8.0 & 5.2 & 13.0 & 4.7 \\
\hline $\begin{array}{l}\text { acid-2-hydroxy-4-methyl } \\
\text { 3-Methylbutanoic acid }\end{array}$ & n.d. & n.d. & 0.5 & n.d. & 0.3 & n.d. & 0.2 & n.d. & 0.4 \\
\hline $\begin{array}{l}\text { Nonanoic acid } \\
\text { Ketons }\end{array}$ & 3.4 & n.d. & n.d. & n.d. & n.d. & n.d. & n.d. & n.d. & n.d. \\
\hline 2-Pentanone & n.d. & 2.8 & 0.6 & 2.4 & 0.7 & 1.8 & 0.6 & 2.3 & 0.5 \\
\hline 2-Heptanone & n.d. & 2.0 & 0.5 & 1.9 & 0.7 & 2.2 & 0.6 & 2.4 & 0.5 \\
\hline $\begin{array}{c}\text { p-Phenylacetophenone } \\
\text { Alcohol }\end{array}$ & 4.2 & n.d. & n.d. & n.d. & n.d. & n.d. & n.d. & n.d. & n.d. \\
\hline Isoamyl alcohol & 4.9 & 23.7 & 42.3 & 27.8 & 50.0 & 44.3 & 51.6 & 21.5 & 59.9 \\
\hline 2-Pentanol & n.d. & n.d. & 0.4 & n.d. & 0.2 & n.d. & 0.2 & n.d. & 0.8 \\
\hline 2-Butanol & n.d. & 1.3 & 0.5 & 1.4 & 0.5 & 1.7 & 0.6 & 2.3 & 0.2 \\
\hline $\begin{array}{l}\text { 2-Phenylethanol } \\
\text { Hydrocarbons }\end{array}$ & 11.3 & n.d. & 2.6 & n.d. & 2.3 & n.d. & 3.9 & n.d. & 2.7 \\
\hline Hexane 2-methyl & n.d. & n.d. & 0.3 & n.d. & 0.5 & n.d. & 0.3 & n.d. & 0.3 \\
\hline Heptane 2,4-dimethyl & 3.2 & 12.2 & 3.4 & 5.6 & 3.2 & 9.5 & 4.6 & 8.5 & 5.1 \\
\hline Octane 4-methyl & n.d. & 4.4 & 0.5 & 1.8 & 0.5 & 3.6 & 0.6 & 2.5 & 0.3 \\
\hline Nonane & 2.2 & n.d. & 0.4 & n.d. & 0.5 & n.d. & 0.7 & n.d. & 0.4 \\
\hline Nonane 2,5-methyl & 2.3 & n.d. & n.d. & n.d. & n.d. & n.d. & n.d. & n.d. & n.d. \\
\hline Decane & 1.8 & n.d. & 0.4 & n.d. & 0.3 & n.d. & 0.5 & n.d. & 0.2 \\
\hline Dodecane & 2.3 & n.d. & n.d. & n.d. & n.d. & n.d. & n.d. & n.d. & n.d. \\
\hline $\begin{array}{l}\text { Hexadecane } \\
\text { Aldeyde }\end{array}$ & 1.7 & n.d. & n.d. & n.d. & n.d. & n.d. & n.d. & n.d. & n.d. \\
\hline Hexanal & 3.2 & 2.6 & 0.2 & 1.7 & 0.4 & 2.0 & 0.2 & 2.8 & 0.2 \\
\hline Heptanal & n.d. & 1.9 & 0.5 & 1.9 & 0.4 & 1.8 & 0.1 & 2.5 & 0.2 \\
\hline $\begin{array}{l}\text { Nonanal } \\
\text { Monoterpene }\end{array}$ & 1.7 & n.d. & n.d. & n.d. & n.d. & n.d. & n.d. & n.d. & n.d. \\
\hline Phellandrene & n.d. & 1.8 & n.d. & 2.5 & n.d. & 1.9 & n.d. & 2.4 & n.d. \\
\hline D-Limonene & 6.3 & n.d. & 12.7 & n.d. & 2.1 & n.d. & 5.0 & n.d. & 0.5 \\
\hline$\alpha$-Pinene & 2.1 & 6.7 & 2.6 & 7.6 & 3.1 & 4.1 & 2.6 & 5.0 & 1.9 \\
\hline $\begin{array}{l}\text { Carene } \\
\text { Esters }\end{array}$ & 1.5 & n.d. & n.d. & n.d. & n.d. & n.d. & n.d. & n.d. & n.d. \\
\hline $\begin{array}{c}\text { Octanoinc acid, ethyl } \\
\text { ester }\end{array}$ & 9.6 & n.d. & 0.4 & n.d. & 0.7 & n.d. & 0.7 & n.d. & 0.6 \\
\hline $\begin{array}{l}\text { Butanedioic acid, diethyl } \\
\text { ester }\end{array}$ & 2.2 & n.d. & n.d. & n.d. & n.d. & n.d. & n.d. & n.d. & n.d. \\
\hline $\begin{array}{c}\text { Decanoic acid, ethyl } \\
\text { ester } \\
\text { Diol }\end{array}$ & 9.7 & n.d. & n.d. & n.d. & n.d. & n.d. & n.d. & n.d. & n.d. \\
\hline 2,3-Butanediol & 20.6 & n.d. & n.d. & n.d. & n.d. & n.d. & n.d. & n.d. & n.d. \\
\hline
\end{tabular}

a Data are means percentage of three replicate expressed as (peak area of each compound/total area of significant peaks) $\times 100$. Abbreviations: n.d., not detecteble. Abbreviations: GPP, grape pomace powder; $\mathrm{CCh}_{15} 36, \mathrm{CCh}_{15} 94, \mathrm{CCh}_{15} 169$ and $\mathrm{CCh}_{15} 190$, control cheese after 15 $\mathrm{d}$ of refrigerate storage with L. lactis MISE36; MISE94, MISE169 and MISE190, respectively; $\mathrm{ECh}_{15} 36, \mathrm{ECh}_{15} 94, \mathrm{ECh}_{15} 169$ and ECh 15190 experimental cheese after $15 \mathrm{~d}$ of refrigerate storage with 1\% of GPP and L. lactis MISE36, MISE94, MISE169 and MISE190, respectively.

A total of 21 VOCs were detected in GPP, whereas 21 and 14 VOCs were identified in cheese samples with and without GPP addition, respectively. Volatile compounds belonging to alkanes, aldehydes, monoterpenes, esters, acids, and ketones were identified in all cheese samples. Acetic acid and 2-hydroxy4-methyl pentanoic acid were the most abundant acids detected in cheese sample without GPP addition. Acetic acid may be 
produced by carbohydrate catabolism by LAB, 2-hydroxy-4-methyl pentanoic acid is formed enzymatically from the corresponding amino acid (L-leucine) [46]. In addition, the free fatty acids (FAA) identified in this study were hexanoic, butyric, and 3-methyl-butanoic acid. Butyric and acetic acids were the main acids identified in cheese sample with GPP addition. FFA contribute to the formation of cheese flavor directly and as precursors of ketones, alcohols, aldehydes, and esters [47,48]. Similar FFA profiles were also observed in other cheeses produced from sheep's milk [41,46]. Two aldehydes (hexenal and heptanal) and one ester (octanoinc acid ethyl ester) were detected in the experimental cheese samples. No ester was identified in the control cheeses. Aldehydes and esters are poorly represented in Vastedda cheeses [49], probably because they are oxidized to acids or reduced to nalkanols due to the enzymatic activities of microorganisms [50]. Isoamyl alcohol, 2-butanol, 2-pentanol, and phenyl-ethyl-alcol were the only alcohols detected in cheese samples with isoamyl alcohol being the major alcohol present in all cheeses. A total of eight hydrocarbons and terpenes were emitted from the cheeses. Terpenes and hydrocarbons originated from the secondary metabolism of plants [51], therefore they can be rapidly transferred into milk fat by forages or other substances added to cheese. In light of the GPP VOCs profile, we can assess that the addition of GPP contributed to increase the amount of isoamyl alcohol and to determine the presence of D-limonene and 2-phenylethanol in the experimental cheeses.

\subsection{Sensory Test}

All cheeses, after 15 days of refrigerated storage, were subjected to the sensory analysis and the results comparing control and experimental samples per each L. lactis strain are reported in Figure 4. The addition of GPP modified the sensory attributes of cheeses. Generally, the addition of fibers or by-products exert a strong effect on the sensory parameters of dairy products $[37,52]$. In this study, except for sweet and bitter that scored similar values in all trials, all other attributes evaluated were consistently influenced by the addition of GPP. In detail, the addition of GPP increased odor and aroma intensity, acid perception, fiber sensation, friability, adhesiveness, and humidity while influenced negatively sweet and hardness attributes. Similar results were observed by Costa et al. [28] who tested white and red wine grape pomace to fortify bovine Primosale cheese. The selected LAB added as starter cultures determined different effects on the sensory attributes of cheeses (Figure $4 a-d$ ). The cheeses produced with the strain Mise94 (with and without GPP) were mostly appreciated by the judges.

\subsection{Functional Properties}

GPP is a rich source of polyphenols, which are the most abundant antioxidants in the human diet with potential health benefits [53]. The antioxidant capacity of GPP-added cheese was investigated only for the cheeses mostly appreciated by the judges; for this reason, $\mathrm{ECh}_{15} 94$ and $\mathrm{CCh}_{15} 94$ were analyzed through $\mathrm{ABTS}{ }^{+}$radical cation decolorization assay. Both cheeses were submitted to the in vitro gastro-intestinal digestion and the ability of reduction of the radical was evaluated from the different digestion steps (Table 5).

Post-oral fraction of the control cheese showed reducing activity that did not significantly $(p>0.05)$ vary after gastric digestion $(0.202 \pm 0.012 \mu \mathrm{mol} \mathrm{TE} / \mathrm{g})$. Milk components, mainly high molecular weight casein, are considered responsible for the antioxidant capacity of the dairy products [54]. Moreover, it was reported that pepsin digestion does not increase radical scavenging activity of purified casein [55]. After intestinal digestion, the antioxidant activity of control $\mathrm{CCh}_{15} 94$ cheese was about $50 \%$ higher than that measured after gastric phase, possibly due to the antioxidant fat-soluble vitamins released in the bile salts micelles or to the amino acids with reducing ability [56,57]. When GPP-added cheese $\left(\mathrm{ECh}_{15} 94\right)$ was submitted to the in vitro digestion, the antioxidant potential of the post-oral fraction was not recorded different from that of the relevant fraction of control cheese $(p>0.05)$, indicating that dilution and homogenization in simulated saliva fluid did not cause polyphenols release (Table 5). Interestingly, a net rise of the reducing activity $(+41 \%)$ was measured in the samples after gastric digestion. As reported by Tagliazucchi et al. [58], 
casein digestion by pepsin can affect the binding with incorporated polyphenols, resulting in their solubilization. The antioxidant activity of $\mathrm{ECh}_{15} 94$ cheese increased also after the intestinal step (Table 5). Finally, all reducing components released through the digestion of both cheeses were solubilized in the bioaccessible fraction, i.e., the soluble fraction of the digesta available for absorption (Table 5). Overall, during the digestion process, with the exception of the oral phase, all fractions obtained from the digestion of the GPP containing cheese showed a much higher antioxidant capacity than GPP-free cheese. The reducing activity of the bioaccessible fraction of $\mathrm{ECh}_{15} 94$ accounted for $175 \%$ of that measured in the corresponding fraction of $\mathrm{CCh}_{15} 94$. Our results demonstrated the important contribution of the polyphenols of GPP to the antioxidant capacity of the cheese and highlighted the functional potential of the fortified product.

Table 5. Antioxidant activity of in vitro digested cheeses measured by ABTS assay.

\begin{tabular}{ccc}
\hline \multirow{2}{*}{ Digestion Step } & CCh $_{\mathbf{1 5}} \mathbf{9 4}$ & ECh $_{\mathbf{1 5}} \mathbf{9 4}$ \\
\cline { 2 - 3 } & \multicolumn{2}{c}{$\boldsymbol{\mu \mathrm { mol } \mathrm { TE } / \mathbf { g }}$} \\
\hline Post-Oral & $0.192 \pm 0.011 \mathrm{~A}$ & $0.215 \pm 0.012 \mathrm{~A}$ \\
Post-Gastric & $0.202 \pm 0.012 \mathrm{~A}$ & $0.304 \pm 0.014 \mathrm{Ba}$ \\
Post-Intestinal & $0.317 \pm 0.015 \mathrm{~B}$ & $0.557 \pm 0.022 \mathrm{Cb}$ \\
Bioaccesible fraction & $0.320 \pm 0.012 \mathrm{~B}$ & $0.556 \pm 0.023 \mathrm{Cb}$ \\
\hline
\end{tabular}

Values are the mean \pm SD of three separate experiments in duplicate. On the row: $\mathrm{a}=p<0.05$ and $\mathrm{b}=p<0.01$ (Student's $t$-test); on the column: A, B, C $=p<0.05$ (Anova one-way followed by Tukey's test). Abbreviations: $\mathrm{CCh}_{15} 94$, control cheese after $15 \mathrm{~d}$ of refrigerate storage with L. lactis MISE94; $\mathrm{ECh}_{15} 94$, experimental cheese after $15 \mathrm{~d}$ of refrigerate storage with $1 \%$ of GPP and L. lactis MISE94.

Unregulated food lipids oxidation during digestion can lead to a postprandial oxidative stress condition, which negatively affects the human health [59]. Consequently, antioxidants contained in foods that are able to react with and detoxify lypoperoxyl radicals can be considered of interest to reduce the oxidative phenomena during digestion. Peroxyl radical scavenger activity of the bioaccessible fractions of the cheeses was compared against lipid oxidation of pig brain microsomes. When lipid peroxidation was induced in microsomes by AAPH in the absence of cheese, TBA-RS production started immediately reaching a maximum at $90 \mathrm{~min}$ incubation (Figure 4). Bioaccessible fraction from $0.1 \mathrm{~g}$ or $0.2 \mathrm{~g}$ of $\mathrm{CCh}_{15} 94$ slightly slowed down TBA-RS formation in a dose-dependent manner. Interestingly, bioaccessible fraction from GPP-enriched cheese $\left(\mathrm{ECh}_{15} 94\right)$ caused a stronger dose-dependent inhibition of the lipid peroxidation, evidenced by the net delay in the initial TBA-RS formation and a higher reduction of TBA-RS production throughout the incubation period (Figure 5).

These results demonstrated that GPP caused $60 \%$ increase of the lipoperoxyl radical scavenger capacity of the cheese measured after digestion, conferring a potential healthy value against postprandial oxidative stress. 


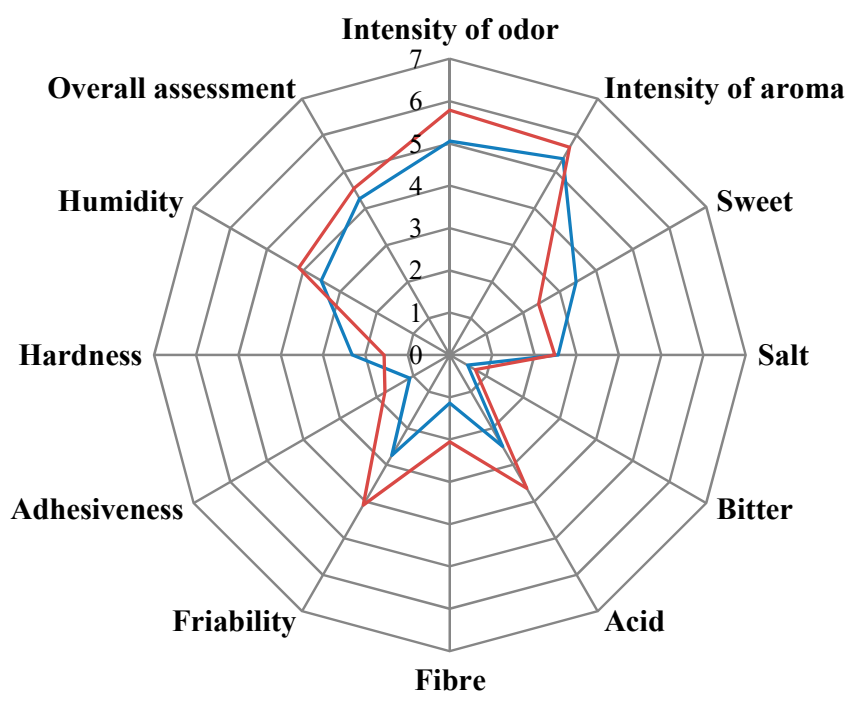

$-\mathrm{CCh}_{15} 36-\mathrm{ECh}_{15} 36$

(a)
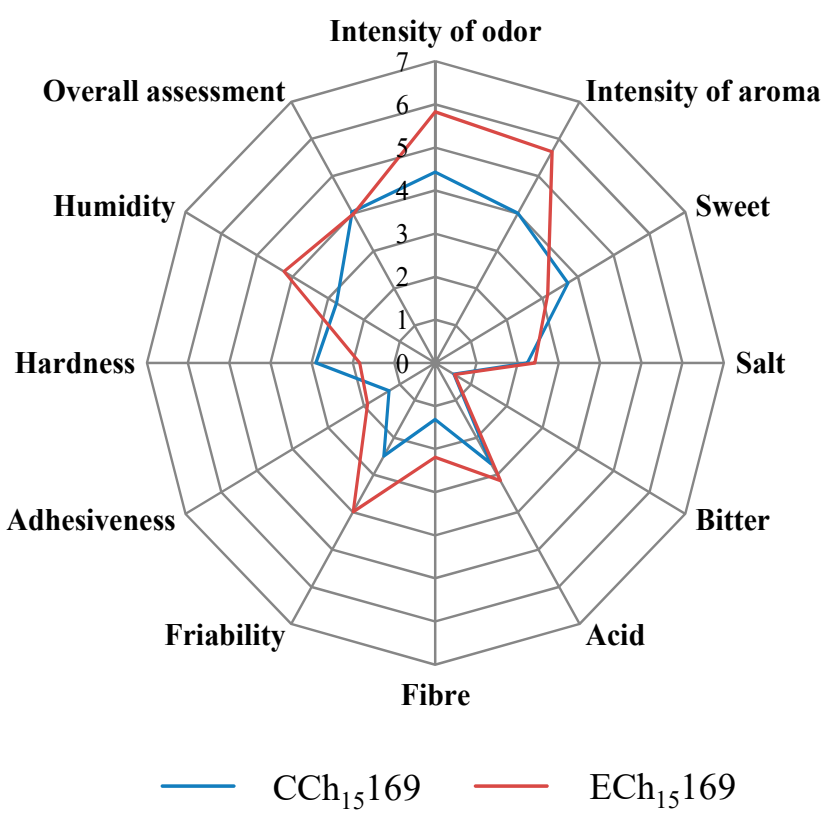

(c)

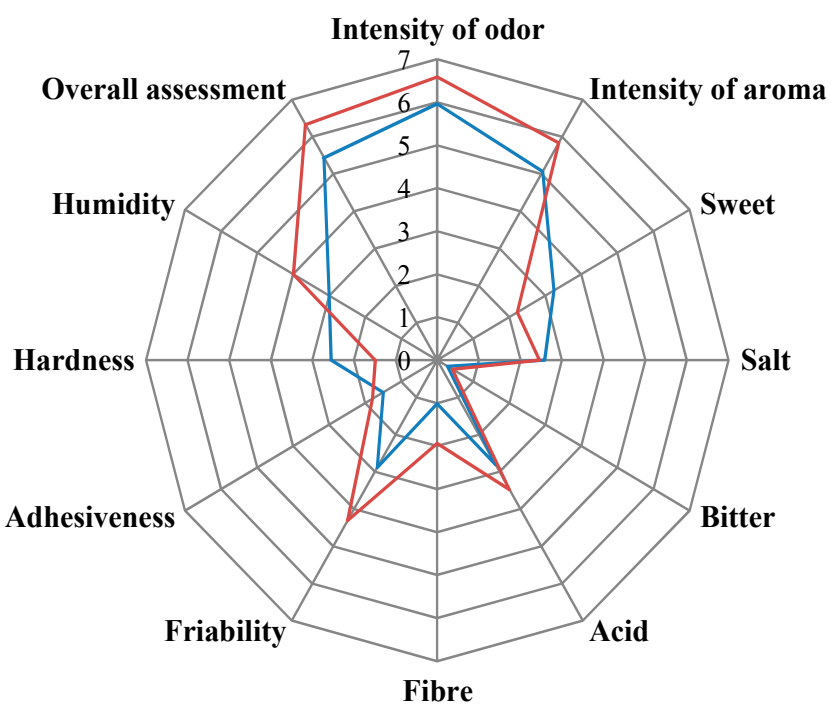

$-\mathrm{CCh}_{15} 94-\mathrm{ECh}_{15} 94$

(b)

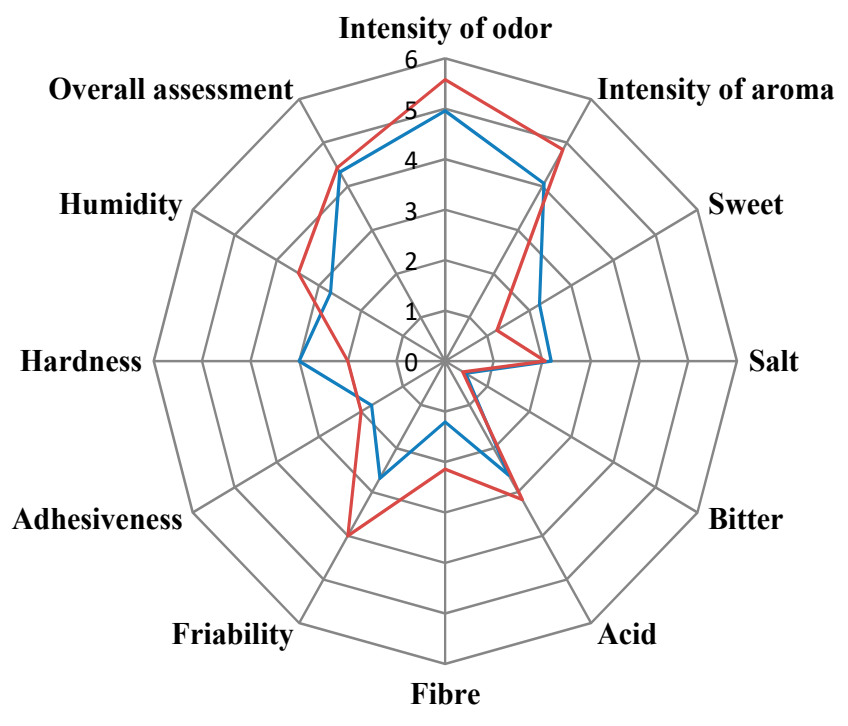

$-\mathrm{CCh}_{15} 190-\mathrm{ECh}_{15} 190$

(d)

Figure 4. Spider diagrams corresponding to the descriptive sensory analysis of cheeses. (a) $\mathrm{CCh}_{15} 36$, control cheese after 15 days of refrigerate storage with $L$. lactis MISE36; $\mathrm{ECh}_{15} 36$, experimental cheese after 15 days of refrigerate storage with $L$. lactis MISE36 + 1\% of GPP; (b) $\mathrm{CCh}_{15} 94$, control cheese after 15 days of refrigerate storage with L. lactis $\mathrm{MISE94} \mathrm{ECh}_{15}$ 94, experimental cheese after 15 days of refrigerate storage with L. lactis MISE94 + 1\% of GPP; (c) CCh 15 169, control cheese after 15 days of refrigerate storage with L. lactis MISE169; $\mathrm{ECh}_{15} 169$, experimental cheese after 15 days of refrigerate storage with L. lactis MISE169+ 1\% of GPP; (d) CCh ${ }_{15}$ 190, control cheese after 15 days of refrigerate storage with L. lactis MISE190; $\mathrm{ECh}_{15} 16$, experimental cheese after 15 days of refrigerate storage with L. lactis MISE190+ 1\% of GPP. 


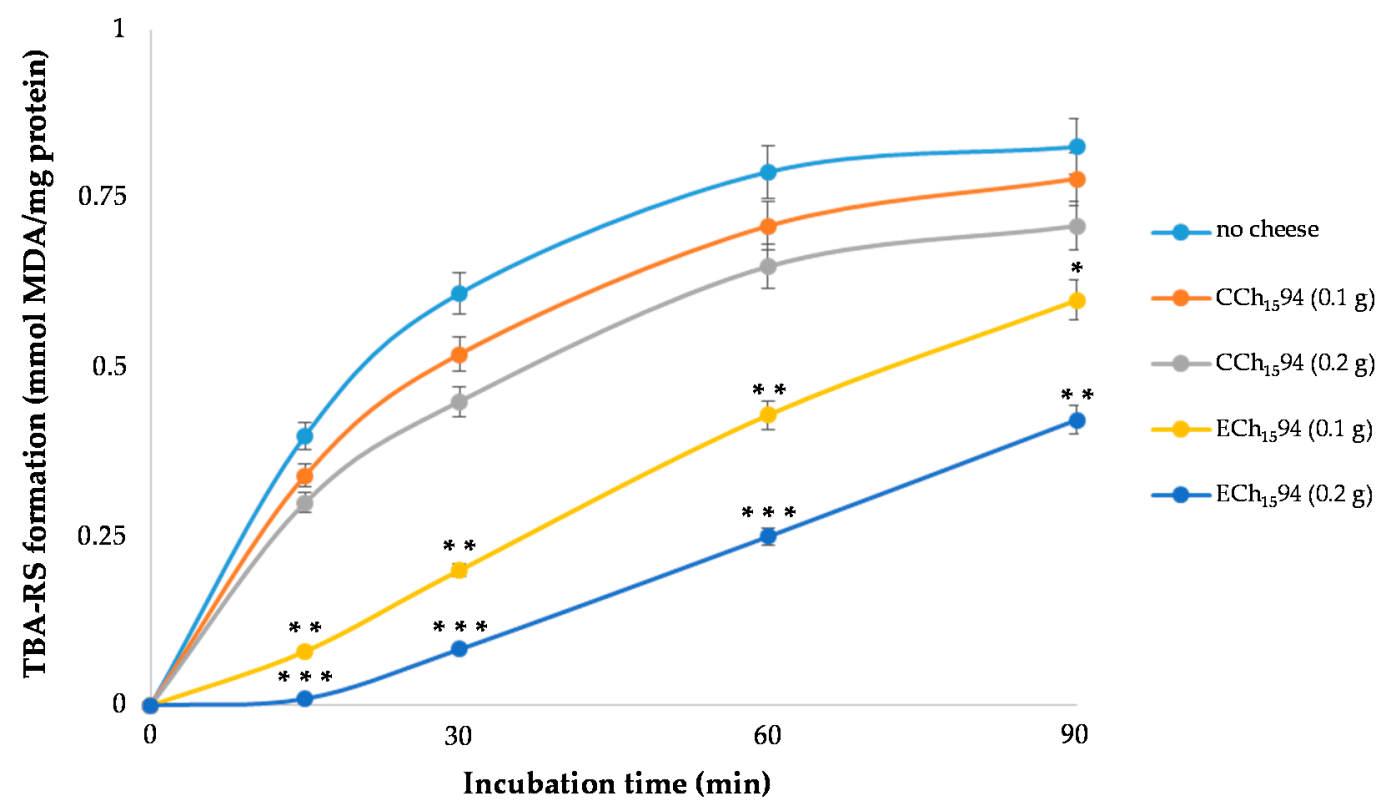

Figure 5. Time-course of thiobarbituric acid-reactive substances (TBA-RS) formation during the AAPH-induced microsomal oxidation, either in the absence (control) or in the presence of bioaccessible fraction obtained after in vitro digestion of cheeses. Microsomes, at $2 \mathrm{mg}$ of protein per $\mathrm{mL}$ of reaction mixture, were submitted to peroxidation by AAH as reported in the Materials and Methods. Each value is the mean $\pm \mathrm{SD}$ of three determinations performed in duplicate. In comparison with the corresponding amount of GPP-free cheese, values are significant with ${ }^{*} p<0.05 ;{ }^{* *} p<0.01 ;{ }^{* *} p<0.0001$. Abbreviations: $\mathrm{CCh}_{15} 94$, control cheese after $15 \mathrm{~d}$ of refrigerate storage with L. lactis MISE94; $\mathrm{ECh}_{15} 94$, experimental cheese after $15 \mathrm{~d}$ of refrigerate storage with 1\% of GPP and L. lactis MISE94.

\section{Conclusions}

This study provided, for the first time, an extended analysis of the microbiological, physicochemical, sensory, and functional aspects of GPP-enriched ovine cheese. The addition of GPP did not alter the microbiological parameters during the fermentation carried out with four strains of L. lactis used as single inoculums. The chemical composition of cheeses was affected by GPP addition. GPP-enriched cheeses were characterized by lower fat content, higher protein content, and higher values of secondary lipid oxidation. The differences in VOCs detected between control and experimental cheeses are a direct consequence of GPP addition. Sensory evaluation indicated that the GPP-enriched cheeses were characterized by a general appreciation by judges and, in particular, the higher values of overall acceptance was detected for the cheeses produced with the strain MISE94. In particular, from the functional point of view, the cheeses enriched with GPP, submitted to simulated human digestion, showed an increased antioxidant activity and lipoperoxyl radical scavenger capacity. Degradation of dairy matrix appears a requisite to release the incorporated polyphenols in GPP-enriched cheese and increase the reducing activity of the intestinal digesta. However, due to the importance of using mixed strain starters to ensure the fermentation process, further studies are necessary to validate this technology for industrial applications.

Author Contributions: Conceptualization, N.F., G.M., and L.S.; methodology, R.G., M.B., L.T., and A.B.; software, R.G. and A.D.G.; validation, R.G., L.T., A.B., and A.A.; formal analysis, L.T., A.B., A.A., A.D.G., and L.S.; investigation, R.G., I.R., M.B., P.B., and M.P.; resources, N.F.; data curation, R.G., A.A., and A.D.G.; writing — original draft preparation, R.G., M.B., L.T., A.B., and L.S.; writing-review and editing, L.S.; project administration, N.F.; funding acquisition, N.F. All authors have read and agreed to the published version of the manuscript.

Funding: This work was financially supported by the project for industrial research "Integrated approach to product development innovations in the leading sectors of the Sicilian agri-food sec- 
tor" Prog. F/050267/03/X32-COR 109494-CUP: B78I17000260008 of the Ministry of the Economic Development, General Management for Business Incentives.

Institutional Review Board Statement: Not applicable.

Informed Consent Statement: Not applicable.

Data Availability Statement: All data included in this study are available upon request by contacting the corresponding author.

Acknowledgments: The authors are grateful to the seasonal fixed-term agricultural staff of the Department of Agricultural, Food and Forest Science-University of Palermo who provided assistance with laboratory analytical activities to this research under the technical and scientific responsibility of the structured personnel of the Department.

Conflicts of Interest: The authors declare that they have no conflict of interest.

\section{References}

1. Mikovà, K. The regulation of antioxidants in foods. In Handbook of Food Preservation; Rahman, M., Ed.; CRC Press: Boca Raton, FL, USA, 2007; Volume 2, pp. 83-267.

2. Torri, L.; Piochi, M.; Marchiani, R.; Zeppa, G.; Dinnella, C.; Monteleone, E. A sensory-and consumer-based approach to optimize cheese enrichment with grape skin powders. J. Dairy Sci. 2016, 99, 194-204. [CrossRef]

3. Bachmann, P. Cheese analogues: A review. Int. Dairy J. 2001, 11, 505-515. [CrossRef]

4. Tomas, M.; Zhang, L.; Zengin, G.; Rocchetti, G.; Capanoglu, E.; Lucini, L. Metabolomic insight into the profile, in vitro bioaccessibility and bioactive properties of polyphenols and glucosinolates from four Brassicaceae microgreens. Food Res. Int. 2021, 140, 110039. [CrossRef]

5. Elejalde, E.; Villarán, M.C.; Alonso, R.M. Grape polyphenols supplementation for exercise-induced oxidative stress. J. Int. Soc. Sports Nutr. 2021, 18, 1-12. [CrossRef]

6. Lavelli, V.; Gallotti, F.; Pedrali, D. Application of compounds from grape processing by-products: Formulation of dietary fiber and encapsulated bioactive compounds. In Food Waste Recovery; Galanakis, C.M., Ed.; Academic Press: Gaithersburg, MD, USA, 2021; pp. 355-366.

7. Marchiani, R.; Bertolino, M.; Ghirardello, D.; McSweeney, P.L.; Zeppa, G. Physicochemical and nutritional qualities of grape pomace powder-fortified semi-hard cheeses. J. Food Sci. Technol. 2016, 53, 1585-1596. [CrossRef]

8. Theagarajan, R.; Narayanaswamy, M.L.; Dutta, S.; Moses, J.A.; Chinnaswamy, A. Valorisation of grape pomace (cv. Muscat) for development of functional cookies. Int. J. Food Sci. Technol. 2019, 54, 1299-1305. [CrossRef]

9. $\quad$ Beres, C.; Costa, G.N.; Cabezudo, I.; da Silva-James, N.K.; Teles, A.S.; Cruz, A.P.; Mellinger-Silva, C.; Tonon, R.V.; Cabral, L.M.C.; Freitas, S.P. Towards integral utilization of grape pomace from winemaking process: A review. Waste Manag. 2017, 68, 581-594. [CrossRef] [PubMed]

10. Fontana, A.R.; Antoniolli, A.; Bottini, R. Grape pomace as a sustainable source of bioactive compounds: Extraction, characterization, and biotechnological applications of phenolics. J. Agric. Food Chem. 2013, 61, 8987-9003. [CrossRef]

11. Aghamirzaei, M.; Peighambardoust, S.H.; Azadmard-Damirchi, S.; Majzoobi, M. Effects of grape seed powder as a functional ingredient on flour physicochemical characteristics and dough rheological properties. J. Agric. Sci. Technol. $2015,17,365-373$.

12. García-Lomillo, J.; Gonzalez-SanJose, M.L.; Del Pino-García, R.; Ortega-Heras, M.; Muñiz-Rodríguez, P. Antioxidant effect of seasonings derived from wine pomace on lipid oxidation in refrigerated and frozen beef patties. LWT Food Sci. Technol. 2017, 77, 85-91. [CrossRef]

13. Sánchez-Alonso, I.; Jiménez-Escrig, A.; Saura-Calixto, F.; Borderías, A.J. Effect of grape antioxidant dietary fibre on the prevention of lipid oxidation in minced fish: Evaluation by different methodologies. Food Chem. 2007, 101, 372-378. [CrossRef]

14. Tseng, A.; Zhao, Y. Wine grape pomace as antioxidant dietary fibre for enhancing nutritional value and improving storability of yogurt and salad dressing. Food Chem. 2013, 138, 356-365. [CrossRef] [PubMed]

15. Barbaccia, P.; Francesca, N.; Di Gerlando, R.; Busetta, G.; Moschetti, G.; Gaglio, R.; Settanni, L. Biodiversity and dairy traits of indigenous milk lactic acid bacteria grown in presence of the main grape polyphenols. FEMS Microbiol. Lett. 2020, 367, fnaa066. [CrossRef] [PubMed]

16. Cruciata, M.; Gaglio, R.; Todaro, M.; Settanni, L. Ecology of Vastedda della valle del Belìce cheeses: A review and recent findings to stabilize the traditional production. Food Rev. Int. 2019, 35, 90-103. [CrossRef]

17. ISO (International Organization for Standardization). Enumeration of Colony-Forming Units of Micro-Organism-Colony-Count Technique at 30 Degrees C. Milk and milk Products; International Standardization Organization (ISO): Geneva, Switzerland, 1992; Volume ISO 6610.

18. Settanni, L.; Di Grigoli, A.; Tornambè, G.; Bellina, V.; Francesca, N.; Moschetti, G.; Bonanno, A. Persistence of wild Streptococcus thermophilus strains on wooden vat and during the manufacture of a Caciocavallo type cheese. Int. J. Food Microbiol. 2012, 155, 73-81. [CrossRef] 
19. Alfonzo, A.; Urso, V.; Corona, O.; Francesca, N.; Amato, G.; Settanni, L.; Di Miceli, G. Development of a method for the direct fermentation of semolina by selected sourdough lactic acid bacteria. Int. J. Food Microbiol. 2016, 239, 65-78. [CrossRef]

20. Cruciata, M.; Gaglio, R.; Scatassa, M.L.; Sala, G.; Cardamone, C.; Palmeri, M.; Moschetti, G.; La Mantia, T.; Settanni, L. Formation and characterization of early bacterial biofilms on different wood typologies applied in dairy production. Appl. Environ. Microbiol. 2018, 84, e02107-e02117. [CrossRef]

21. Weisburg, W.; Barns, S.M.; Pelletier, D.A.; Lane, D.J. 16S ribosomal DNA amplification for phylogenetic study. J. Bacteriol. 1991, 173, 697-703. [CrossRef]

22. IDF (International Dairy Federation). Cheese and Processed Cheese Product. Determination of the Total Solids Content. Standard FIL-IDF 4A; International Dairy Federation: Brussels, Belgium, 1982.

23. IDF (International Dairy Federation). Cheese and Processed Cheese Product. Determination of Fat Content-Gravimetric Method. Standard FIL-IDF 5B; International Dairy Federation: Brussels, Belgium, 1986.

24. IDF (International Dairy Federation). Determination of the Protein Content of Processed Cheese Products. Standard FIL-IDF 25; International Dairy Federation: Brussels, Belgium, 1964.

25. IDF (International Dairy Federation). Determination of the Ash Content of Processed Cheese Products. Standard FIL-IDF 27; International Dairy Federation: Brussels, Belgium, 1964.

26. Bonanno, A.; Di Grigoli, A.; Vitale, F.; Di Miceli, G.; Todaro, M.; Alabiso, M.; Gargano, M.L.; Venturella, G.; Anike, F.N.; Isikhuemhen, O.S. Effects of feeding diets supplemented with medicinal mushrooms myceliated grains on some production, health and oxidation traits of dairy ewes. Int. J. Med. Mushrooms 2019, 21, 89-103. [CrossRef]

27. ISO (International Organization for Standardization). Sensory Analysis e General Guidance for the Design of Test Rooms; International Standardization Organization (ISO): Geneva, Switzerland, 2007; Volume 8589.

28. Costa, C.; Lucera, A.; Marinelli, V.; Del Nobile, M.A.; Conte, A. Influence of different by-products addition on sensory and physicochemical aspects of Primosale cheese. J. Food Sci. Technol. 2018, 55, 4174-4183. [CrossRef]

29. Faccia, M.; Angiolillo, L.; Mastromatteo, M.; Conte, A.; Del Nobile, M.A. The effect of incorporating calcium lactate in the saline solution on improving the shelf life of fiordilatte cheese. Int. J. Dairy Technol. 2013, 66, 373-381.

30. Attanzio, A.; Diana, P.; Barraja, P.; Carbone, A.; Spanò, V.; Parrino, B.; Cascioferro, S.M.; Allegra, M.; Cirrincione, G.; Tesoriere, L.; et al. Quality, functional and sensory evaluation of pasta fortified with extracts from Opuntia ficus-indica cladodes. J. Sci. Food Agric. 2019, 99, 4242-4247. [CrossRef]

31. Attanzio, A.; Tesoriere, L.; Allegra, M.; Livrea, M.A. Monofloral honeys by Sicilian black honeybee (Apis mellifera ssp. sicula) have high reducing power and antioxidant capacity. Heliyon 2016, 2, e00193. [CrossRef]

32. Bradford, M.M. A rapid and sensitive method for quantitation of microgram quantities of protein utilizing the principle of protein-dye binding. Anal. Biochem. 1976, 72, 248-254. [CrossRef]

33. Gaglio, R.; Scatassa, M.L.; Cruciata, M.; Miraglia, V.; Corona, O.; Di Gerlando, R.; Portolano, B.; Moschetti, G.; Settanni, L. In vivo application and dynamics of lactic acid bacteria for the four-season production of Vastedda-like cheese. Int. J. Food Microbiol. 2014, 177, 37-48. [CrossRef]

34. Mainente, F.; Menin, A.; Alberton, A.; Zoccatelli, G.; Rizzi, C. Evaluation of the sensory and physical properties of meat and fish derivatives containing grape pomace powders. Int. J. Food Sci. Technol. 2019, 54, 952-958. [CrossRef]

35. Franciosi, E.; Settanni, L.; Cologna, N.; Cavazza, A.; Poznanski, E. Microbial analysis of raw cows' milk used for cheese-making: Influence of storage treatments on microbial composition and other technological traits. World J. Microbiol. Biotechnol. 2011, 27, 171-180. [CrossRef]

36. Rynne, N.M.; Beresford, T.P.; Kelly, A.L.; Guinee, T.P. Effect of milk pasteurisation temperature on age-related changes in lactose metabolism, $\mathrm{pH}$ and the growth of non-starter lactic acid bacteria in half-fat Cheddar cheese. Food Chem. 2007, 100, 375-382. [CrossRef]

37. Gaglio, R.; Gentile, C.; Bonanno, A.; Vintaloro, L.; Perrone, A.; Mazza, F.; Barbaccia, P.; Settanni, L.; Di Grigoli, A. Effect of saffron addition on the microbiological, physicochemical, antioxidant and sensory characteristics of yoghurt. Int. J. Dairy Technol. 2019, 72, 208-217. [CrossRef]

38. Dumalisile, P.; Witthuhn, R.C.; Britz, T.J. Impact of different pasteurization temperatures on the survival of microbial contaminants isolated from pasteurized milk. Int. J. Dairy Technol. 2005, 58, 74-82. [CrossRef]

39. Settanni, L.; Gaglio, R.; Guarcello, R.; Francesca, N.; Carpino, S.; Sannino, C.; Todaro, M. Selected lactic acid bacteria as a hurdle to the microbial spoilage of cheese: Application on a traditional raw ewes' milk cheese. Int. Dairy J. 2013, 32, 126-132. [CrossRef]

40. Gaglio, R.; Cruciata, M.; Di Gerlando, R.; Scatassa, M.L.; Cardamone, C.; Mancuso, I.; Sardina, M.T.; Moschetti, G.; Portolano, B.; Settanni, L. Microbial activation of wooden vats used for traditional cheese production and evolution of the neo-formed biofilms. Appl. Environ. Microbiol. 2016, 82, 585-595. [CrossRef]

41. Gaglio, R.; Cruciata, M.; Scatassa, M.L.; Tolone, M.; Mancuso, I.; Cardamone, C.; Corona, O.; Todaro, M.; Settanni, L. Influence of the early bacterial biofilms developed on vats made with seven wood types on PDO Vastedda della valle del Belìce cheese characteristics. Int. J. Food Microbiol. 2019, 291, 91-103. [CrossRef]

42. Settanni, L.; Moschetti, G. Non-starter lactic acid bacteria used to improve cheese quality and provide health benefits. Food Microbiol. 2010, 27, 691-697. [CrossRef] 
43. Todaro, M.; Palmeri, M.; Settanni, L.; Scatassa, M.L.; Mazza, F.; Bonanno, A.; Di Grigoli, A. Effect of refrigerated storage on microbiological, chemical and sensory characteristics of a ewes' raw milk stretched cheese. Food Packag. Shelf Life 2017, 11, 67-73. [CrossRef]

44. Ribeiro, L.F.; Ribani, R.H.; Francisco, T.M.G.; Soares, A.A.; Pontarolo, R.; Haminiuk, C.W.I. Profile of bioactive compounds from grape pomace (Vitis vinifera and Vitis labrusca) by spectrophotometric, chromatographic and spectral analyses. J. Chromatogr. B 2015, 1007, 72-80. [CrossRef] [PubMed]

45. Guarrasi, V.; Sannino, C.; Moschetti, M.; Bonanno, A.; Di Grigoli, A.; Settanni, L. The individual contribution of starter and non starter lactic acid bacteria to the volatile organic compound composition of Caciocavallo Palermitano cheese. Int. J. Food Microbiol. 2017, 259, 35-42. [CrossRef]

46. Kırmac1, H.A.; Hayaloğlu, A.A.; Özer, H.B.; Atasoy, A.F.; Levent, O. Effects of wild-type starter culture (artisanal strains) on volatile profile of urfa cheese made from ewe milk. Int. J. Food Prop. 2015, 18, 1915-1929. [CrossRef]

47. Smit, G.; Smit, B.A.; Engels, W.J. Flavour formation by lactic acid bacteria and biochemical flavour profiling of cheese products. FEMS Microbiol. Rev. 2005, 29, 591-610. [CrossRef]

48. Thierry, A.; Collins, Y.F.; Mukdsi, M.C.A.; McSweeney, P.L.H.; Wilkinson, M.G.; Spinnler, H.E. Lipolysis and metabolism of fatty acids in cheese. In Cheese: Chemistry, Physics, and Microbiology; McSweeney, P.L.H., Fox, P.F., Cotter, P.D., Everett, D.W., Eds.; Academic Press: Gaithersburg, MD, USA, 2017; Volume 1, pp. 423-444.

49. Todaro, M.; Palmeri, M.; Cardamone, C.; Settanni, L.; Mancuso, I.; Mazza, F.; Corona, O. Impact of packaging on the microbiological, physicochemical and sensory characteristics of a "pasta filata" cheese. Food Packag. Shelf Life 2018, 17, 85-90. [CrossRef]

50. Muñoz, N.; Ortigosa, M.; Torre, P.; Izco, J.M. Free amino acids and volatile compounds in an ewe's milk cheese as affected by seasonal and cheese-making plant variations. Food Chem. 2003, 83, 329-338. [CrossRef]

51. Abilleira, E.; de Renobales, M.; Nájera, A.I.; Virto, M.; de Gordoa, J.C.R.; Pérez-Elortondo, F.J.; Albisu, M.; Barron, L.J.R. An accurate quantitative method for the analysis of terpenes in milk fat by headspace solid-phase microextraction coupled to gas chromatography-mass spectrometry. Food Chem. 2010, 120, 1162-1169. [CrossRef]

52. Abd Elhamid, A.M. Physicochemical, rheological and sensory properties of Egyptian Kariesh cheese containing wheat bran. Int. J. Dairy Technol. 2016, 69, 425-432. [CrossRef]

53. Fraga, C.G.; Croft, K.D.; Kennedy, D.O.; Tomás-Barberán, F.A. The effects of polyphenols and other bioactives on human health. Food Funct. 2019, 10, 514-528. [CrossRef]

54. Helal, A.; Tagliazucchi, D.; Verzelloni, E.; Conte, A. Gastro-pancreatic release of phenolic compounds incorporated in a polyphenols-enriched cheese-curd. Food Sci. Technol. 2015, 60, 957-963. [CrossRef]

55. Petrat-Melin, B.; Andersen, P.; Rasmussen, J.T.; Poulsen, N.A.; Larsen, L.B.; Young, J.F. In vitro digestion of purified b-casein variants A1, A2, B, and I: Effects on antioxidant and angiotensin-converting enzyme inhibitory capacity. J. Dairy Sci. 2014, 98, 15-26. [CrossRef] [PubMed]

56. Gupta, A.; Mann, B.; Kumar, R.; Sangwan, R.B. Antioxidant activity of Cheddar cheeses at different stages of ripening. Int. J. Dairy Technol. 2009, 62, 339-347. [CrossRef]

57. Lucas, A.; Agabriel, C.; Martin, B.; Ferlay, A.; Verdier-Metz, I.; Coulon, J.B.; Rock, E. Relationships between the conditions of cow's milk production and the contents of components of nutritional interest in raw milk farmhouse cheese. Le Lait 2006, 86, 177-202. [CrossRef]

58. Tagliazucchi, D.; Helal, A.; Verzelloni, E.; Conte, A. The type and concentration of milk increased the in vitro bioaccessibility of coffee chlorogenic acids. J. Agric. Food Chem. 2012, 60, 11056-11064. [CrossRef]

59. Ursini, F.; Sevanian, A. Postprandial oxidative stress. Biol. Chem. 2002, 383, 599-605. [CrossRef] 